\title{
Source rock properties and kerogen decomposition kinetics of Eocene shales from petroliferous Barmer basin, western Rajasthan, India
}

Nihar Ranjan Kar ${ }^{1}$, Devleena Mani*1 ${ }^{1}$, Soumyajit Mukherjee ${ }^{2 *}$, Swagato Dasgupta ${ }^{3}$, Mohit Kumar Puniya $^{4}$, Ashish Kumar Kaushik ${ }^{5}$, Mery Biswas ${ }^{6}$, E.V.S.S.K. Babu ${ }^{7}$

${ }^{1}$ Center for Earth, Ocean and Atmospheric sciences (CEOAS), University of Hyderabad, Gachibowli, Hyderabad, 500046, INDIA

${ }^{2}$ Department of Earth Sciences, Indian Institute of Technology Bombay, Powai, Mumbai, 400076, Maharashtra, INDIA

${ }^{3}$ Department of Applied Geophysics, Indian Institute of Technology (ISM) Dhanbad, Jharkhand, INDIA

${ }^{4}$ National Geotechnical Facility, Survey of India, Dehradun 248001, Uttarakhand, INDIA

${ }^{5}$ Department of Geology, Kurukshetra University, Kuruksetra 136119, Haryana, INDIA

${ }^{6}$ Department of Geography, Presidency University, Kolkata 700073, West Bengal, INDIA

${ }^{7}$ Council Of Scientific And Industrial Research-National Geophysical Research Institute, Uppal

Road, Habsiguda, Hyderabad 500 007, Telangana, INDIA

*Authors for correspondence: soumyajitm@gmail.com, smukherjee@iitb.ac.in

dtiwarisp@uohyd.ac.in

STATEMENT: This article is a non-peer reviewed preprint, submitted to EarthArXi. The article has been submitted to the Journal of Natural Gas Science and Engineering. 


\section{Source rock properties and kerogen decomposition kinetics of Eocene shales from petroliferous Barmer basin, western Rajasthan, India}

Nihar Ranjan Kar ${ }^{1}$, Devleena Mani*1, Soumyajit Mukherjee ${ }^{2 *}$, Swagato Dasgupta ${ }^{3}$, Mohit Kumar Puniya $^{4}$, Ashish Kumar Kaushik ${ }^{5}$, Mery Biswas ${ }^{6}$, E.V.S.S.K. Babu ${ }^{7}$

${ }^{1}$ Center for Earth, Ocean and Atmospheric sciences (CEOAS), University of Hyderabad, Gachibowli, Hyderabad, 500046, INDIA

${ }^{2}$ Department of Earth Sciences, Indian Institute of Technology Bombay, Powai, Mumbai, 400076, Maharashtra, INDIA

${ }^{3}$ Department of Applied Geophysics, Indian Institute of Technology (ISM) Dhanbad, Jharkhand, INDIA

${ }^{4}$ National Geotechnical Facility, Survey of India, Dehradun 248001, Uttarakhand, INDIA

${ }^{5}$ Department of Geology, Kurukshetra University, Kuruksetra 136119, Haryana, INDIA

${ }^{6}$ Department of Geography, Presidency University, Kolkata 700073, West Bengal, INDIA

${ }^{7}$ Council Of Scientific And Industrial Research-National Geophysical Research Institute, Uppal Road, Habsiguda, Hyderabad 500 007, Telangana, INDIA

*Authors for correspondence: soumyajitm@gmail.com, smukherjee@iitb.ac.in dtiwarisp@uohyd.ac.in

\section{Abstract}


Hydrocarbon exploration and production are going on in Barmer basin (Rajasthan, India) for more than a decade. The potential source rocks are of Paleocene - Eocene age, and Mesozoic siltstones form the reservoirs. The western and central portions of the Rajasthan basin are characterised by extensive lignite formations, which can be promising for artificial transformation to oil and gas. We study the source rock properties, depositional environments and hydrocarbon generation potential of the Paleogene lignitic shales of the Giral lignite mine and the Cretaceous Sarnu siltstones for their source and reservoir rock potentiality. The total organic carbon content (TOC) of the Giral samples range between $0.76-49.83$ wt\% and the thermal maturity, as reflected by the pyrolysis $\mathrm{T}_{\max }$, lies between $412-468{ }^{\circ} \mathrm{C}$. Sarnoo siltstones, on the other hand, have a very low TOC ranging from $0.02-0.08 \mathrm{wt} \%$ and a $\mathrm{T}_{\max }$ of $320-608{ }^{\circ} \mathrm{C}$. The higher TOC and a lower oxygen index (OI) of Giral lignites and shaly lignites indicate the prevalence of a reducing depositional environment. Bulk organic geochemical parameters involving kerogen pyrolysis and thermal degradation kinetics indicate a more promising hydrocarbon generation potential in the lignite than shales, which, however exhibits higher thermal maturity of organic matter. Giral lignites as well as shales show dominantly Type-III heterogeneous kerogen, which is sourced from terrestrial organic matter. This is also corroborated by a broader distribution of activation energy derived from the thermal decomposition of the kerogen. The kerogen transformation ratio (KTR) and the hydrocarbon generation rate (HGR) suggest a considerably earlier and quicker kerogen transformation. Samples from the Sarnoo area offer no significant information on the source rock characteristics, due to their lean organic nature. However, lignites and shaly lignites of the Giral mine are identified as excellent candidates for their suitability towards easy conversion into hydrocarbon products through artificial techniques. 
Keywords: Source rock; Barmer basin; hydrocarbon; TOC; kerogen kinetics

\section{Highlights:}

$>$ Hydrocarbon generation potential and source rock kinetics of Barmer basin studied.

$>$ Organic matter in shaly lignites characterised by high TOC and thermally mature Type III kerogen.

$>$ Kerogen decomposition kinetics suggests relatively earlier and faster temperature of transformation for shaly lignites.

Shaly lignites promising candidate for artificial maturation into oil and gas.

\section{Introduction}

Organic-rich shales form important source rocks for the petroleum systems of several prolific basins of the world, including India. Often, the over mature, oil-prone source rock also stores the adsorbed and free gaseous hydrocarbons in its fine-grained matrix and pore spaces. The exploitation of this natural gas from shales through hydraulic fracking has revolutionised the unconventional shale gas production in the last decade. Rising demands and search for the newer and alternate hydrocarbon resources, besides the conventional ones, spurs to explore the generation potentials of organically rich lignites and shaly lignites, which, too, act as suitable source rocks under certain conditions (Mahlstedt and Horsfield, 2012; Raju et al., 2013).

The Rajasthan basin in NW India is a Category-1 sedimentary basin with an established prolific commercial production of hydrocarbons (DGH, 2022). The basin is also characterisedby extensive lignite mines, which comprise of thick sequences of organic-rich horizons of shales, lignites and shaly lignites. These lignite deposits occur in mid-Eocene formation, and are spread over 70,000 $\mathrm{km}^{2}$ in the Barmer-Sanchor, Jaisalmer and Nagaur sub-basins of Rajasthan. The 
palynological, petrographic and physico-chemical properties of Rajasthan lignites have been studied by several workers since last 100 years (e.g., Oldham 1886, Dolson at al., 2015; Singh et al., 2016). Barmer successions hold immense potential for unconventional hydrocarbon resources such as shale gas and shale oil (Mahlstedt and Horsfield, 2012; Raju et al., 2013). Lignitic coals here are relatively younger in age and have not been subject to extreme temperature-pressure conditions of maturation, as compared with other high-ranking Indian coals. As a result, these coals have high volatile content, and thus, can easily be converted to oil and gas through coal liquefaction and gasification, respectively (Raju et al., 2013). A classic exampleis the Tertiary coals of the Assam basin, NE India, which also constitute the primary source rock for oil generation (Raju et al., 2013).

The organic richness in lignites is defined by its total organic carbon content (TOC), while the organic matter source (lacustrine, marine or terrestrial) determines its kerogen quality. Thermal maturity of lignites is a function of tectonics and sedimentary overburden pressure. Quality and thermal maturity of the organic content constitute important evaluation parameters for which a hydrocarbon source rocks are assessed critically (Peters and Cassa, 1994; Rodriguez and Philp, 2010; Mani et al., 2015). While bulk organic parameters provide significant insights on these properties, a quantitative estimate regarding the hydrocarbon generation potential of source rocks can be obtained using kerogen degradation kinetics, which predicts the amount of hydrocarbons generated as a function of temperature and time (Tissot and Welte, 1984; Mani et al., 2015), 
The lignite deposits of Rajasthan have been studied for their bulk and compound specific organic matter compositions (Paul and Dutta (2016), macerals (Kumar et al. 2020), coal rank and properties (Singh et al (2018), elemental compositions (Rajak et al., 2018) and biostratigraphy and paleoenvironmental conditions (Prasad et al., 2019). Though many of previous studies suggest the excellent organic properties of Rajasthan lignites, none have adopted the quantitative approach to understand the hydrocarbon generation potential of these lignites. Thermal decomposition of kerogen with time provides important kinetic parameters such as activation energies of kerogen degradation, transformation ratios and quantitative generation potential, which when integrated with basinal geology (stratigraphy and heat flow) provide robust inputs for the basin modelling studies for hydrocarbon generation and expulsion.

In this study, we investigate the source rock properties and quantitative hydrocarbon generation potential of shales, lignites, shaly lignites and siltstones of the Barmer basin of Rajasthan. All producing fields in Barmer basin belong to the Upper Cretaceous to Lower Tertiary sequences (Paleocene to Eocene; Dolson et al. 2015; Kothari et al. 2015). The Tertiary shales are the source rocks for its petroleum system and the sandstones and silty sandstones the effective reservoirs. For the present study, the shales and carbonaceous lignites have been sampled from the Giral mines. Regions adjacent to Giral, such as Kapurdi ( $37 \mathrm{~km}$ away) have been shown to have excellent hydrocarbon source potential based on the petrographic and geochemical studies (Rajak et al., 2021). The siltstones have been collected from the Sarnooarea of the Barmer basin, where the Mesozoic sequences crop out. The objective of the study is to elucidate the organic matter content, thermal maturity and hydrocarbon generation potential of the lignites using bulk organic geochemistry and kerogen degradation kinetics. The results obtained using the Rock 
Eval pyrolysis of Barmer lignites, combined with the kinetic model, demonstrate the quantitative hydrocarbon generation capacities and source and reservoir behaviour of the rocks.

\section{Geology}

The Rajasthan basin (Fig. 1a) with an areal extent of 1,26,000 $\mathrm{km}^{2}$ has proven, commercial production of hydrocarbons (DGH, 2021). It encompasses Barmer-Sanchor, Bikaner-Nagaur, and Jaisalmer sub-basins. In the Barmer sub-basin, Eocene Lower Barmer Hill Formation (Farrimond et al., 2015) is the major source rock, and this, along with the Fatehgarh Formation constitutes the major hydrocarbon reservoirs (Dasgupta and Mukherjee 2017). These formations have been identified in different wells drilled in the central and northern part of the basin.

The tectonics and depositional environment of the Barmer basin has been studied widely. Dasgupta and Mukherjee (2017) in their repository compiled the stratigraphy of this basin. Dasgupta and Mukherjee (2019) and Biswas et al. (2022) presented the morphotectonics of this basin in some detail. Meso-scale structures in this basin are available as a chapter in an atlas (Mukherjee et al. 2020). 

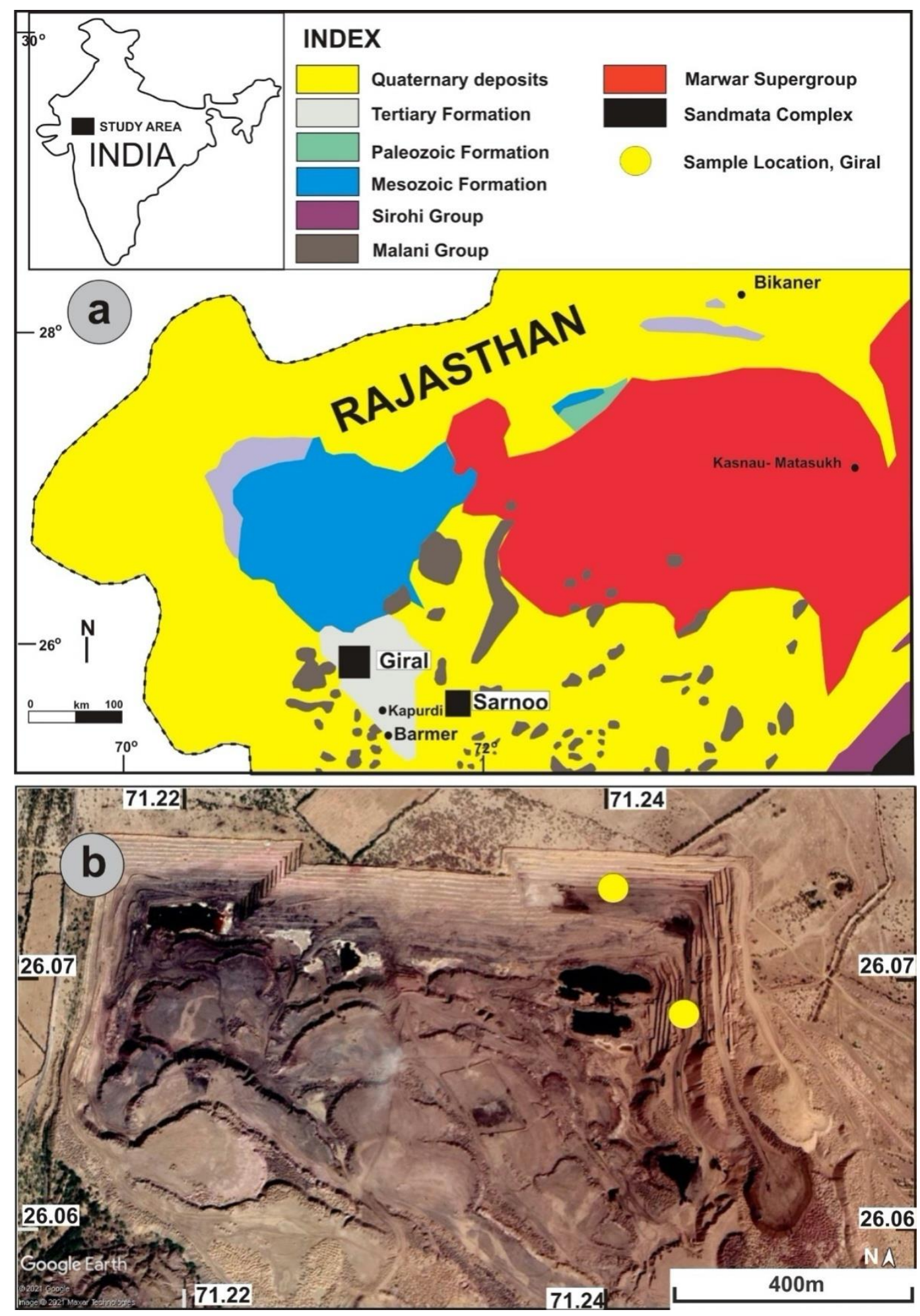

Fig. 1a.Geologic map of Barmer basin (modified after Roy and Jakhar, 2002). Locations of samples from Giral and Sarnoo are shown. b. Google Earth image of the Giral mine. Yellow circles: sample locations. 
Eocene sulphur-rich lignite-bearing sedimentary sequences occur in the Barmer basin (Singh et al. 2020). Giral mine (Fig. 1b) is located $\sim 43 \mathrm{~km} \mathrm{~N}$ of the Barmer city. The Giral Member corresponds to the Dharvi Dungar Formation (DDF), which formed primarily in a lacustrine environment with alternating shale, sandstone and lignite deposits (Dolson et al., 2014; Farrimond et al., 2015). The main stratigraphic members of DDF, from bottom to top, include Mandai, Giral and Kapurdi, which are mostly shale-dominated units with extensive lignite horizons. It has been proposed that the Giral Member belongs to the Late Paleocene (Thanetian) to Early Eocene fossiliferous Akli Formation (Farrimond et al., 2015; Rajkumari and Guntupalli, 2020). The lithology of the Giral mine rocks has been quoted a as "shales, carbonaceous shales and lignite seam of the Akli Formation at the bottom portion and bentonitic clay of the Akli Formation in its upper part" (Rajkumari and Guntupalli, 2020). Lithologs of the Giral mine have been presented by the several workers (Singh 2015; Paul and Dutta 2016; Prasad et al. 2020; Rajkumari and Guntupalli 2020). Giral rocks are typically devoid of sandy lithology (Prasad et al. 2020). Researchers have reported $30 \mathrm{~cm}$ to $1.5 \mathrm{~m}$ thick lignite seams, separated by $50 \mathrm{~cm}$ to 5 m thick carbonaceous/grey shales from this mine area (Paul and Dutta 2016; Prasad et al., 2020). Studying the dinoflagellates, Prasad et al. (2020) demarcated five units of the rock succession in the Giral mine and interpreted them in terms of system tracks and transgressions (also see Singh et al., 2015). The Giral Member of Akli unit deposited mainly in a lacustrine environment (Raju et al., 2013, Dolson et al., 2015; Farrimond et al., 2015; Singh et al., 2016; Rajak et al., 2021). Mangroves are the main source of the organic matter input (Raju et al., 2013). Sporadic presence of dinoflagellates, ostracods and fish (Tripathy et al., 2009) indicate some sort of marine 
incursion into the basin either from south (Dolson et al., 2014; Farrimond et al., 2015) or from the Devikot high region of the north.

Palynofloral studies by Tripathy et al. (2009) suggest that the Giral mine sequences were deposited in a coastal swampy environment, surrounded by prolific mangrove vegetation, where the marine water was mixed with the non-marine water. Fossil studies suggest a paleoenvironment of dense tropical evergreen to semi-evergreen low-land forest (Singh, 2015; Khnolkar and Sharma (2019).

\section{Materials \& methods}

\subsection{Sampling}

A total of 19 samples with 10 lignites, shaly lignites and shales from the Giral mine (Figs. 2,3) and 9 samples of Sarnoo siltstone (Figs. 4,5) were collected from the outcrops of the Sarnoo region. The samples were washed with Milli-Q water, air-dried and crushed into fine powder using an agate mortar. A rock-eval pyrolysis instrument, equipped with OPTKIN software (Version 3.0.3, 2014) was used to generate the bulk organic geochemical parameters and kerogen decomposition kinetics, respectively, for all the samples at Rock-Eval lab of the CSIR-NGRI, Hyderabad. 


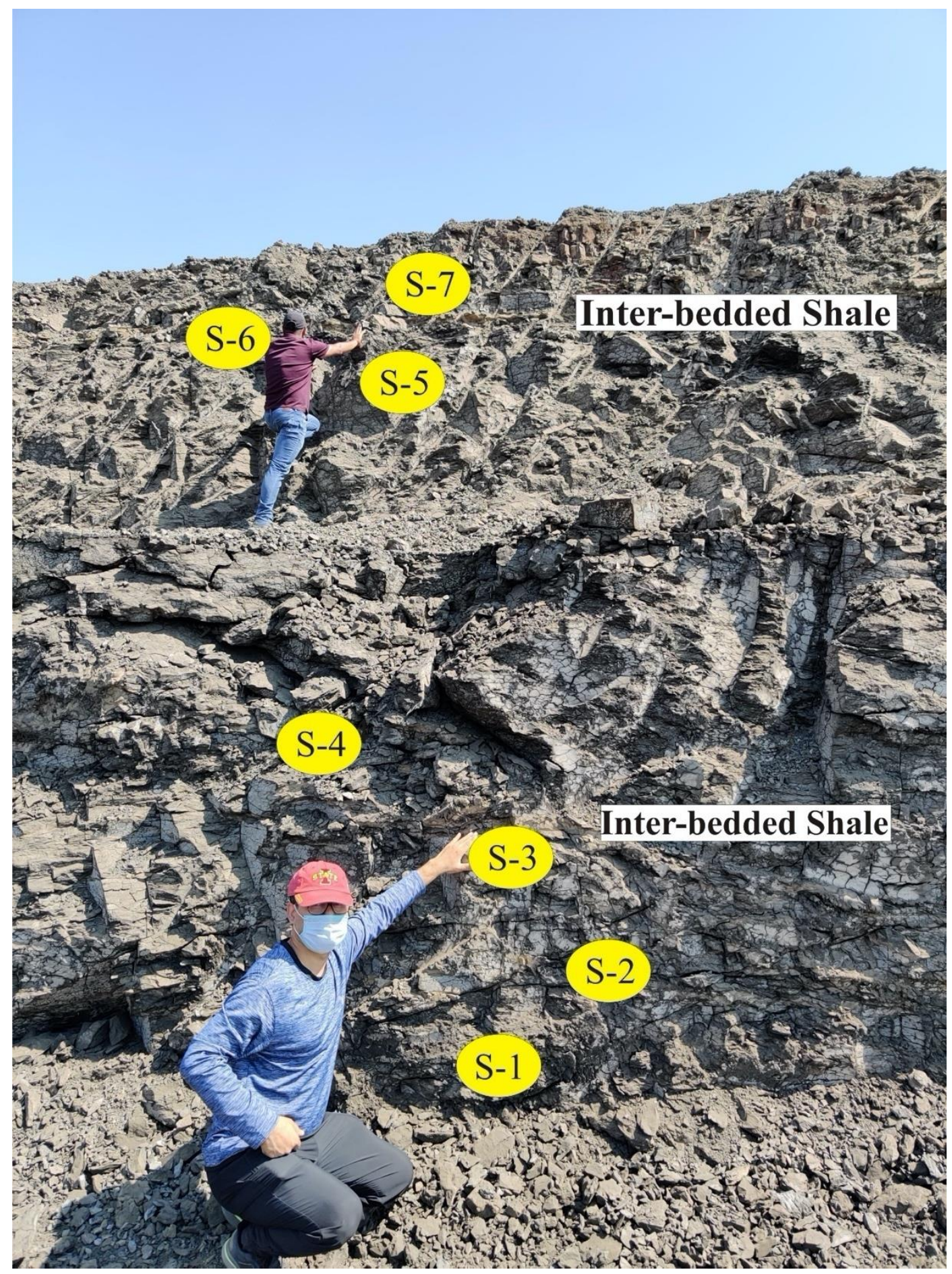

Fig. 2. Outcrop in Giral mine. Sample locations $S-1$ to 7 shown. Coordinate: 26.04334 N, 071.14923 E. Two thin interbedded shale horizons found between lignite deposits. 


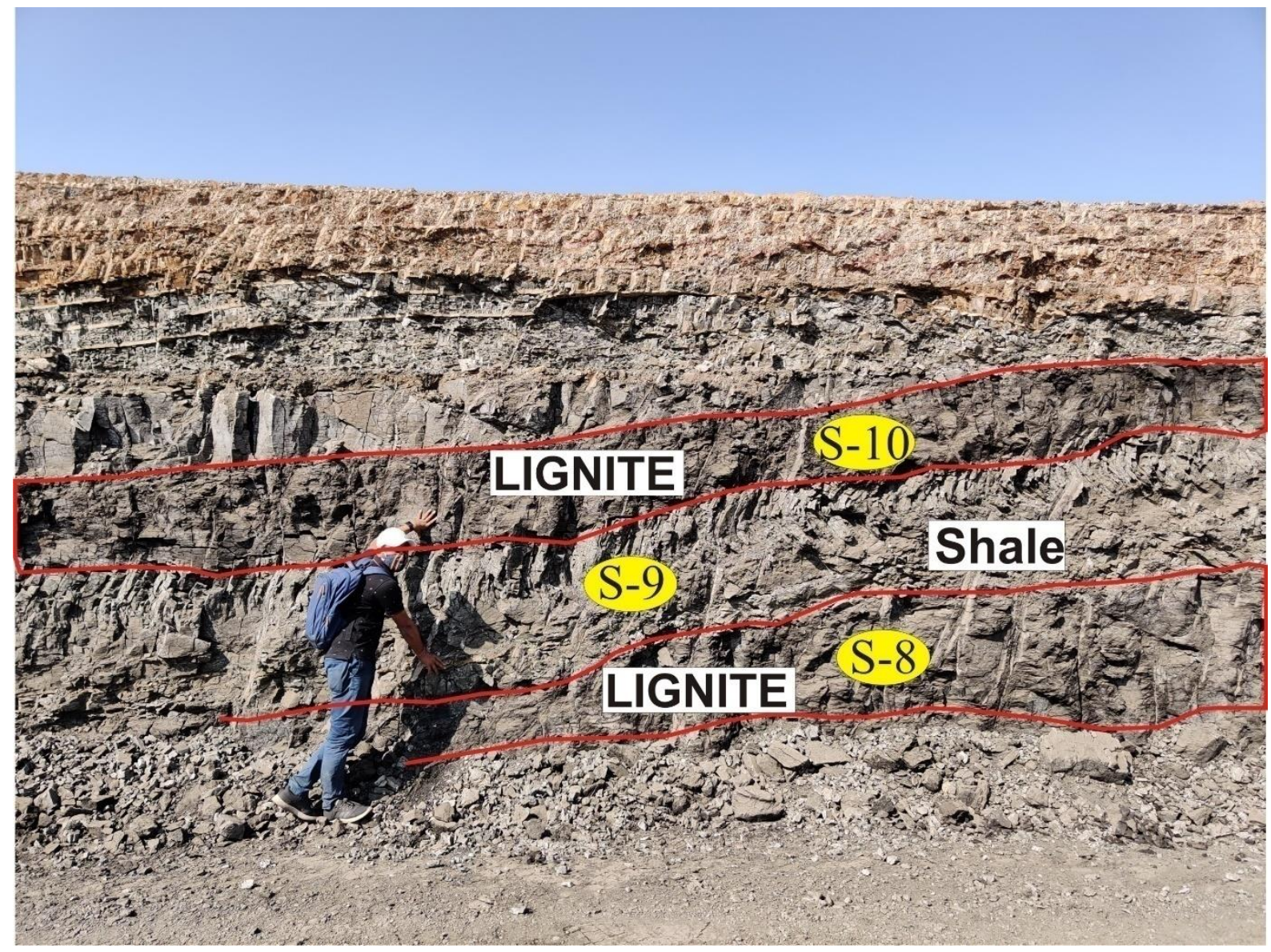

Fig. 3. Sample locations 8 to $10(26.04334$ N, 071.14923 E) from the Giral mine. Two coal seams with an interbedded shale horizon. 


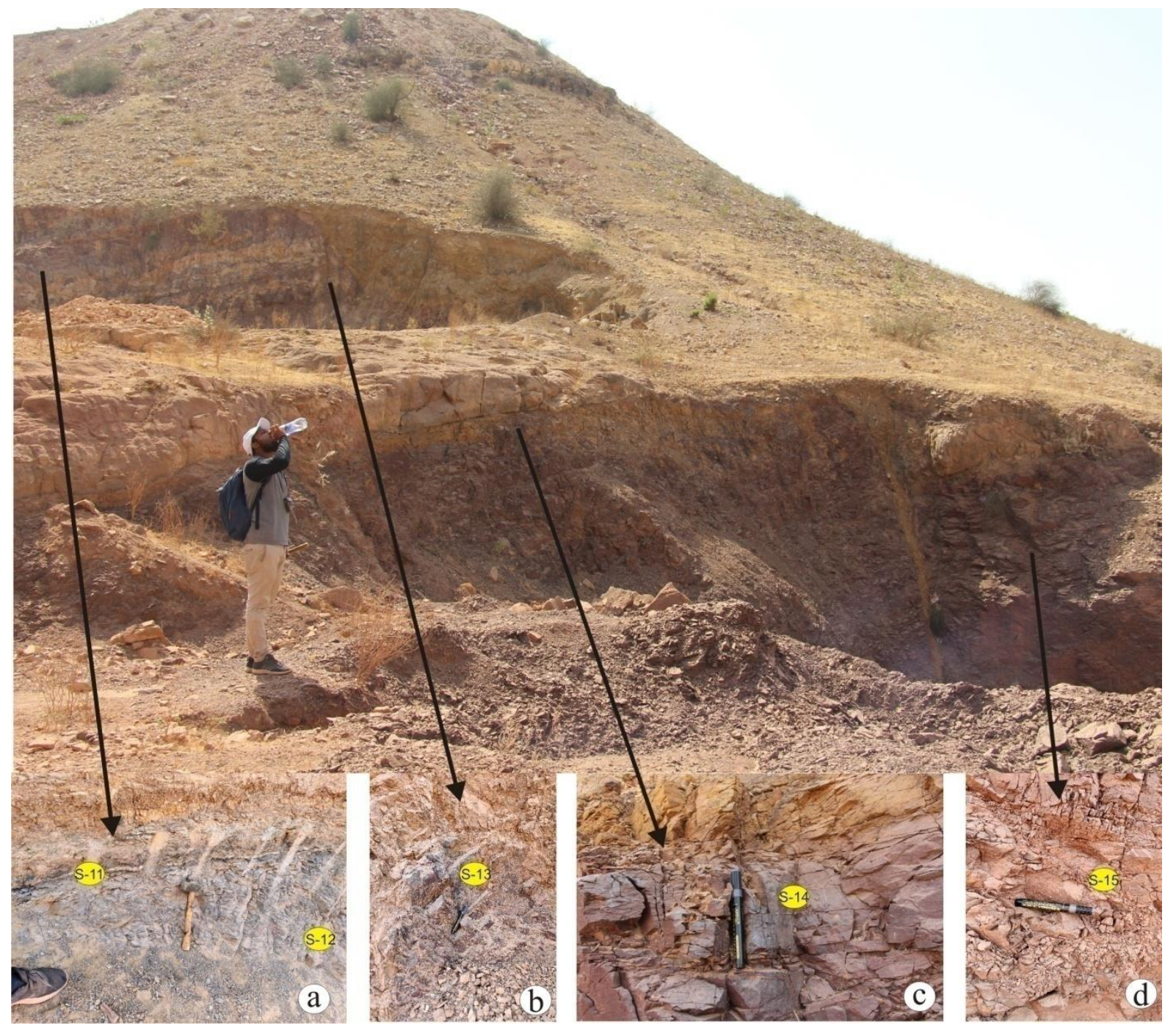

Fig. 4._Sarnoo siltstones in well-exposed outcrop in the Sarnoo region (25.69325 N, 71.79791 E).Horizons of sample collection: ' $a$ ', ' $b$ ', ' $c$ ' and ' $d$ '. 


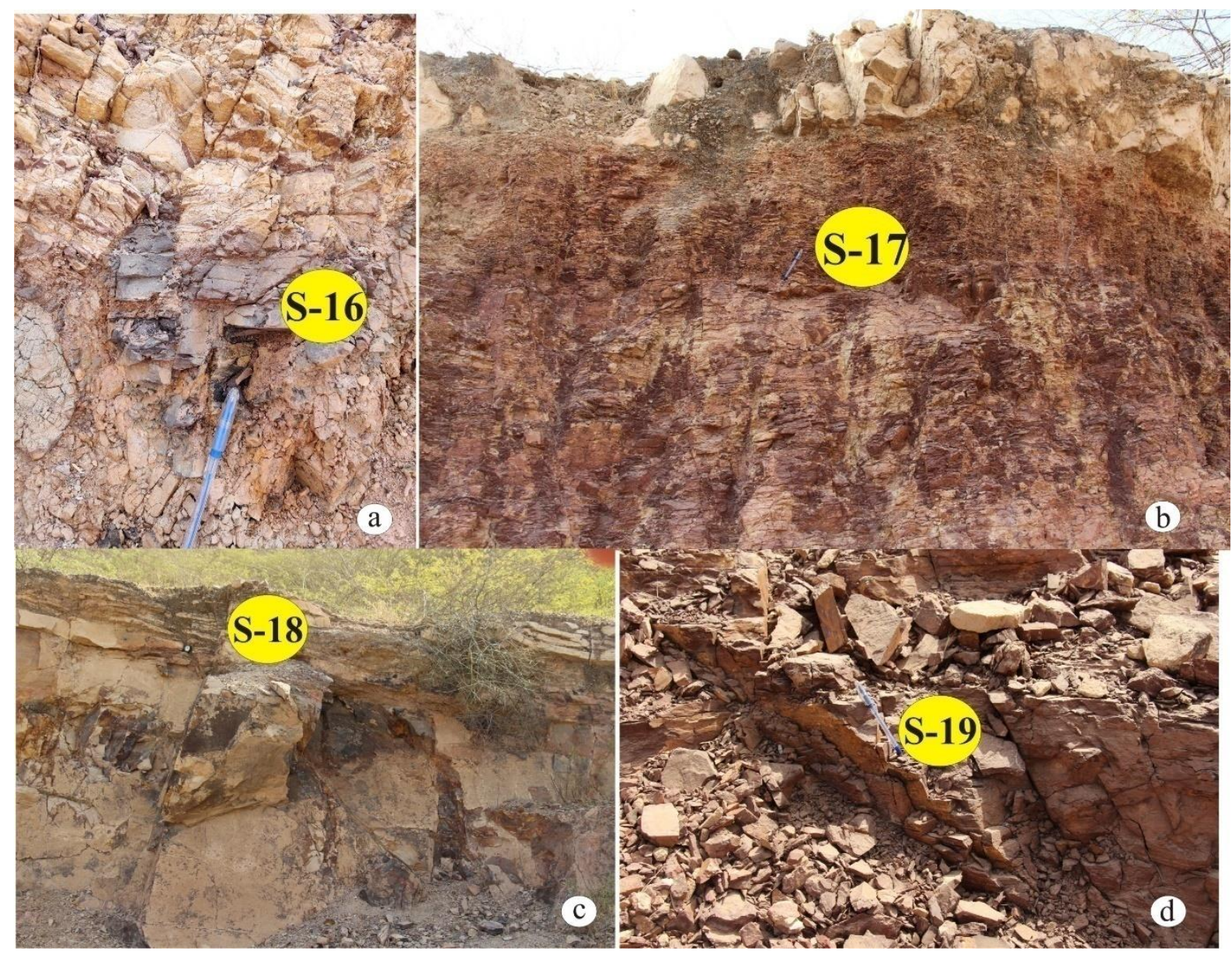

Fig. 5. Sarnoo siltstones in a well-exposed outcrop in the Sarnoo region. Horizons of sample collection: ' $a$ ', ' $b$ ', 'c' and ' $d$ '. Pen is as marker for Figs ' $a$ ', ' $b$ ' and 'c'; pen length $\sim 11 \mathrm{~cm}$. For 'c': clinometer as the marker. GPS for sample ' $a$ ' is 25.68908N 71.78901E; for ' $b$ ', 'c' and 'd': 25.66812N 71.77608E. 


\subsection{Bulk organic geochemical parameters}

About 50-60 mg of homogenised shales and siltstones and 5-10 mg of lignite samples were analysed for their bulk organic geochemical properties. A Turbo version of Rock Eval 6 pyrolyser, equipped with two programmed pyrolysis and oxidation ovens was used. The pyrolyzed and the oxidised products were measured through in-built detectors, the [flame ionization detector; FID and infrared (IR)]. Samples were run in the basic cycle of the instrument, wherein the pyrolysis oven temperature was maintained between $300-650{ }^{\circ} \mathrm{C}$ with an episodic ramp and hold. Hydrocarbons released by the cracking of kerogen were detected by the FID and the $\mathrm{CO}, \mathrm{CO}_{2}$ released were detected by the IR detector. The temperature for the oxidation oven was programmed between $300-850{ }^{\circ} \mathrm{C}$ with an episodic ramp and hold. The important parameters obtained are as follows:

$\mathrm{S} 1$ = amount of free hydrocarbons (in milligrams of hydrocarbon per gram of rock).

S2 = amount of hydrocarbons generated through thermal cracking of kerogen. S2 indicates quantity of hydrocarbons that the rock has potential to produce, should burial and maturation to continue.

$\mathrm{S} 3=$ the amount of $\mathrm{CO}_{2}$ (in $\mathrm{mg}$ of $\mathrm{CO} 2$ per gm of rock produced during pyrolysis of kerogen. S3 indicates the amount of oxygen in the kerogen and is used to calculate the oxygen index.

Tmax $=$ the temperature at which the maximum release of hydrocarbons from cracking of kerogen occurs during pyrolysis (top of S2 peak). Tmax indicates the maturation stage of the organic matter. 
These acquired parameters are used to calculate:

Hydrogen Index: HI = [(100 x S20)/TOC $]$ and Oxygen Index: OI = [(100 x S3)/TOC $]$.

\subsection{Kerogen kinetics}

The kinetic study for thermal decomposition of kerogen has been carried out using Rock Eval pyrolysis. It involves temperature and time-programming, where the immature organic-rich samples can be matured artificially at raised temperatures with varied reaction rates in laboratory conditions (using Rock Eval Pyrolizer and OPTKIN program) to find out the activation energies, kerogen transformation and natural rates of hydrocarbon generation. The optimization programme OPTKIN determines kinetic parameters of thermal cracking of kerogen, as a function of time and temperature; and is based on several rock-eval pyrolysis reactions carried out on immature source-rock samples.

Optkin is based on the kinetic model of Tissot and Espitalie (1975), which predicts the amount of hydrocarbon generated by primary cracking of a kerogen when temperature increases through time. The thermal degradation of kerogen follows several n-parallel reactions, and obeys Arrhenius law and the first-order kinetics to transform into oil and gas.

The rate of the reactions involved in the transformation of kerogen to oil and gas can be represented as,

$\mathrm{dq}_{\mathrm{i}} / \mathrm{dt}=-\mathrm{k}_{\mathrm{i}} * \mathrm{q}_{\mathrm{i}}$

(Eqn 1)

where, 
$\mathrm{dq}_{\mathrm{i}} / \mathrm{dt}=$ rate of hydrocarbon generation (coincides with the $\mathrm{S} 2$ peak of the pyrolysis curve), $\mathrm{k}_{\mathrm{i}}=$ the rate constant for the $\mathrm{i}^{\text {th }}$ equation, which depends on the absolute temperature,

$\mathrm{q}_{\mathrm{i}}=$ the amount of pyrolysable organic matter by the reaction $\mathrm{i}$.

The negative sign before $\mathrm{k}_{\mathrm{i}}$ connotes decrease in the organic matter concentration as the reaction proceeds.

Eqn (1) follows the Arrhenius first-order kinetics:

$\mathrm{k}_{\mathrm{i}}(\mathrm{T})=\mathrm{A} \exp \left(-\mathrm{E}_{\mathrm{i}} / \mathrm{RT}\right)$ (Eqn2)

Here $\mathrm{A}=$ Arrhenius constant $\left(\mathrm{s}^{-1}\right), \mathrm{E}_{\mathrm{i}}=$ Activation energy related to reaction $\mathrm{i}\left(\mathrm{Jmole}^{-1}\right), \mathrm{R}=$ Molar gas constant $\left(0.00199 \mathrm{kcal} \mathrm{mole}^{-1}\right), \mathrm{T}=$ Absolute temperature $(\mathrm{K})$.

Eliminating $\mathrm{k}_{\mathrm{i}}$ from Eqns (1) and (2):

$\mathrm{dq}_{\mathrm{i}} / \mathrm{dt}=\mathrm{A} \exp \left(-\mathrm{E}_{\mathrm{i}} / \mathrm{RT}\right) * \mathrm{q}_{\mathrm{i}}$

The total initial petroleum potential (mgHC/gTOC) of the kerogen is

$H I=\sum_{i=1}^{n}\left(x i_{0}\right)$

where $\mathrm{xi}_{0}$ is an initial petroleum potential of the organic matter involved in reaction $\mathrm{i}$ ( $\mathrm{mgHC} / \mathrm{gTOC})$; the value of $\mathrm{x}_{\mathrm{i}}$ at $\mathrm{t}$ is 0 .

The amount of generated hydrocarbons ( $\mathrm{Q} \mathrm{mgHC} / \mathrm{gTOC})$ is given by:

$Q=\sum_{i=1}^{n}\left(x i_{0}-x i\right)$ 
For the present OPTKIN kinetic study, four immature $\left(\mathrm{T}_{\max }=420-430{ }^{\circ} \mathrm{C}\right)$ shaly lignites and one early mature $\left(T_{\max } 443^{\circ} \mathrm{C}\right)$ shale sample were taken. Three fractions of each sample, weighing $50 \mathrm{mg}$, were heated with variable rates of 5,15 , and $30{ }^{\circ} \mathrm{C} \mathrm{min}-1$ with an initial temperature of $300{ }^{\circ} \mathrm{C}$ to a final temperature of $700{ }^{\circ} \mathrm{C}$ during pyrolysis. Following this, samples were oxidized with the heating rate of $20{ }^{\circ} \mathrm{C} \min ^{-1}$ and within $300-850{ }^{\circ} \mathrm{C}$ temperature range. Assuming that the rate constant of kerogen decomposition depends on temperature, as per the Arrhenius equation (eqn 1), the computation was achieved through mathematical optimizations of experimental rock eval pyrolysis data, primarily the pyrolysis temperatures, heating rates, S2 and HI. Optkin determines various sets of kinetic parameters for the activation energies (E) and frequency factor (A). (Tissot and Espitalié, 1975; Braun and Burnham, 1987). The aim of optimization is to determine the best fit for the activation energy distribution ( $\mathrm{A}, \mathrm{Ei}, \mathrm{X} \mathrm{i}_{0}$ ). For each pyrolysis curve used for optimization, Optkin gives a comparison between the measured and computed petroleum potential HI (in $\mathrm{mg} / \mathrm{g}$ TOC), S2 peak temperature Tmax (in ${ }^{0} \mathrm{C}$ ), amount $\mathrm{Q}$ of generated hydrocarbon (in $\mathrm{mg} / \mathrm{g}$ TOC, from 0 to $\mathrm{HI}$ ), Hydrocarbon generation rates $\left(\frac{\mathrm{dQ}}{\mathrm{dt}}\right)$ (in $\mathrm{mg} / \mathrm{g}$ TOC/deg. C); and transformation ratios (TR) from kerogen to hydrocarbon (in $\%$, from 0 to $100 \%$ ) using the equation:

$\mathrm{TR}=\frac{Q}{H I}$

\section{Results}

\subsection{Bulk organic geochemical parameters}


The TOC values of the Giral mine range between 0.76-49.83 wt\% (Table 1).The lignite samples show quite high TOC of 16.39-48.83 wt $\%$ (average $=30.76$; Standard Deviation; SD $=17.21$ $\mathrm{wt} \%$ ), followed by shaly lignites $1.94-5.24 \mathrm{wt} \%$ (average $=3.03 ; \mathrm{SD}=1.54 \mathrm{wt} \%$ ) and shales, $0.76-1.62 \mathrm{wt} \%$ (average= 1.05; SD $0.49 \mathrm{wt} \%$ ). A fair to good range of organic matter content is represented by the samples. The Sarnoo siltstone samples show extremely low TOC values, ranging from 0.02-0.08 (average $=0.04 ; \mathrm{SD}=0.02 \mathrm{wt} \%$ ) (Table 1$)$. The siltstones are very lean in organic matter concentration. Surficially exposed Sarnoo samples have experienced oxidative weathering, which is also reflected with its higher oxygen index (OI) value.

Table 1. Rock-Eval pyrolysis parameter data for shales/shaly lignites from the Giral mine and the Sarnoo region. GM: Giral mines, SR: Sarnoo region.

\begin{tabular}{|c|c|c|c|c|c|c|c|c|c|c|c|c|}
\hline Sample & LITHOLOGY & Qty & $\begin{array}{l}\text { TOC } \\
(\%)\end{array}$ & $\begin{array}{l}\mathbf{T}_{\max } \\
\left(\text { in }{ }^{\circ} \mathrm{C}\right)\end{array}$ & $\begin{array}{l}\text { S1 } \\
\text { (mg } \\
\text { HC } \\
\text { g }^{-1} \\
\text { roc } \\
\text { k) }\end{array}$ & 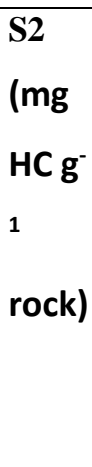 & $\begin{array}{l}\mathrm{S3} \\
\text { (mg } \\
\mathrm{HC} \mathrm{g}^{-} \\
1 \\
\text { rock) }\end{array}$ & $\begin{array}{l}\text { S2/S3 } \\
\text { (no } \\
\text { unit) }\end{array}$ & $\begin{array}{l}\text { HI } \\
\text { (m } \\
\mathrm{g} \\
\mathrm{HC} \\
\mathrm{g}^{-} \\
{ }^{1} \mathrm{TO} \\
\mathrm{C})\end{array}$ & 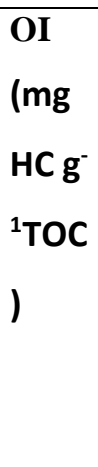 & $\begin{array}{l}\text { PI } \\
\text { (No } \\
\text { unit) }\end{array}$ & $\begin{array}{l}\text { EVRO } \\
\text { (\%VR) }\end{array}$ \\
\hline S-1 & Lignites (GM) & 10.39 & 49.83 & 412 & 3.05 & 95.91 & 23.99 & 3.99 & 192 & 48 & 0.03 & 0.256 \\
\hline $\mathrm{S}-2$ & Shaly lignites (GM) & 60.49 & 5.24 & 430 & 0.18 & 4.84 & 4.11 & 1.17 & 92 & 78 & 0.04 & 0.58 \\
\hline S-3 & Shale (GM) & 60.46 & 1.62 & 443 & 0.09 & 1.48 & 7.91 & 0.18 & 91 & 488 & 0.06 & 0.814 \\
\hline
\end{tabular}




\begin{tabular}{|c|c|c|c|c|c|c|c|c|c|c|c|c|}
\hline S-4 & Shaly lignites (GM) & 60.46 & 2.93 & 427 & 0.15 & 2.14 & 3.4 & 0.62 & 73 & 116 & 0.07 & 0.526 \\
\hline S-5 & Shaly lignites (GM) & 60.96 & 1.94 & 420 & 0.22 & 1.36 & 1.05 & 1.29 & 70 & 54 & 0.14 & 0.4 \\
\hline S-6 & Shale (GM) & 60.33 & 0.76 & 468 & 0.14 & 0.66 & 3.29 & 0.20 & 87 & 433 & 0.18 & 1.264 \\
\hline S-7 & Shaly lignites (GM) & 60.39 & 2 & 430 & 0.13 & 1.8 & 3.1 & 0.58 & 90 & 155 & 0.07 & 0.58 \\
\hline $\mathrm{S}-8$ & Lignites (GM) & 11.29 & 26.06 & 424 & 1.07 & 36.21 & 14.93 & 2.42 & 139 & 57 & 0.03 & 0.472 \\
\hline S-9 & Shale (GM) & 60.32 & 0.77 & 437 & 0.12 & 0.59 & 7.02 & 0.08 & 77 & 912 & 0.17 & 0.706 \\
\hline S-10 & Lignites (GM) & 60.8 & 16.39 & 427 & 1.72 & 70.92 & 5.21 & 13.61 & 433 & 32 & 0.02 & 0.526 \\
\hline S-11 & Clay siltstone (SR) & 60.45 & 0.05 & 607 & 0.05 & 0.16 & 0.58 & 0.27 & 320 & 1160 & 0.26 & 3.766 \\
\hline S-12 & Clay siltstone(SR) & 60.24 & 0.08 & 369 & 0.08 & 0.24 & 0.8 & 0.3 & 300 & 1000 & 0.26 & -0.518 \\
\hline S-13 & $\begin{array}{l}\text { Reddish siltstone } \\
\text { (SR) }\end{array}$ & 60.59 & 0.04 & 606 & 0.05 & 0.13 & 0.62 & 0.20 & 325 & 1550 & 0.28 & 3.748 \\
\hline S-14 & Reddish siltstone(SR) & 60.62 & 0.02 & 608 & 0.04 & 0.1 & 0.37 & 0.27 & 500 & 1850 & 0.27 & 3.784 \\
\hline S-15 & Reddish siltstone(SR) & 60.99 & 0.03 & 608 & 0.04 & 0.09 & 0.52 & 0.17 & 300 & 1733 & 0.3 & 3.784 \\
\hline S-16 & Reddish siltstone(SR) & 61.12 & 0.02 & 320 & 0.04 & 0.1 & 0.25 & 0.4 & 500 & 1250 & 0.28 & -1.4 \\
\hline S-17 & $\begin{array}{l}\text { Siltstone with clay } \\
\text { (SR) }\end{array}$ & 61.02 & 0.04 & 608 & 0.06 & 0.16 & 0.78 & 0.20 & 400 & 1950 & 0.26 & 3.784 \\
\hline S-18 & $\begin{array}{l}\text { Burnt out siltstone } \\
\text { (SR) }\end{array}$ & 60.33 & 0.03 & 607 & 0.04 & 0.11 & 0.58 & 0.18 & 367 & 1933 & 0.24 & 3.766 \\
\hline S-19 & $\begin{array}{l}\text { Reddish black } \\
\text { siltstone(SR) }\end{array}$ & 61.19 & 0.02 & 335 & 0.03 & 0.08 & 0.47 & 0.17 & 400 & 2350 & 0.3 & -1.13 \\
\hline $\begin{array}{l}\text { Averag } \\
\mathrm{e}\end{array}$ & Coal (GM) & & 30.76 & 421 & 1.95 & 67.68 & 14.71 & 6.68 & $\begin{array}{l}254 . \\
66\end{array}$ & 45.66 & 0.03 & 0.42 \\
\hline SD & Coal (GM) & & 17.21 & 7.94 & 1.01 & 29.98 & 9.39 & 6.05 & $\begin{array}{l}156 . \\
69\end{array}$ & 12.66 & 0.01 & 0.14 \\
\hline $\begin{array}{l}\text { Averag } \\
\mathrm{e}\end{array}$ & Shaly lignites (GM) & & 3.03 & 426.75 & 0.17 & 2.54 & 2.91 & 0.92 & $\begin{array}{l}81.2 \\
5\end{array}$ & $\begin{array}{l}100.7 \\
5\end{array}$ & 0.08 & 0.52 \\
\hline SD & Shaly lignites (GM) & & 1.54 & 4.72 & 0.04 & 1.57 & 1.31 & 0.37 & $\begin{array}{l}11.3 \\
5\end{array}$ & 44.26 & 0.04 & 0.08 \\
\hline $\begin{array}{l}\text { Averag } \\
\mathrm{e}\end{array}$ & Shale (GM) & & 1.05 & 449.3 & 0.12 & 0.91 & 6.07 & 0.16 & 85 & 611 & 0.14 & 0.93 \\
\hline SD & Shale (GM) & & 0.49 & 16.44 & 0.03 & 0.49 & 2.45 & 0.06 & 7.21 & $\begin{array}{l}262.1 \\
2\end{array}$ & 0.07 & 0.29 \\
\hline $\begin{array}{l}\text { Averag } \\
\mathrm{e}\end{array}$ & Siltstone (SR) & & 0.04 & 518.66 & 0.05 & 0.13 & 0.55 & 0.24 & $\begin{array}{l}379 . \\
11\end{array}$ & $\begin{array}{l}1641 . \\
77\end{array}$ & 0.27 & 2.18 \\
\hline SD & Siltstone (SR) & & 0.02 & 133.59 & 0.01 & 0.05 & 0.17 & 0.07 & 78.4 & 438.6 & 0.02 & 2.40 \\
\hline
\end{tabular}




\begin{tabular}{|l|l|l|l|l|l|l|l|l|l|l|l|l|}
\hline & & & & & & & & & 1 & 0 & & \\
\hline
\end{tabular}

The S1 (amount of volatile hydrocarbon) peak for the Giral mines sample ranges between 0.09$3.05 \mathrm{mgHCg}^{-1}$ rock, suggesting a high value for lignites than shales and shaly lignites. The Sarnoo siltstones show the S1 peak between 0.03-0.08 $\mathrm{mgHC} \mathrm{g}^{-1}$ rock (Table 1). The S2 peak (amount of hydrocarbon that gets generated from the thermal cracking of kerogen) for the Giral is observed between $0.59-95.91 \mathrm{mgHC}^{-1}$ rock, suggesting a good hydrocarbon generation potential. A low range of $0.09-0.24 \mathrm{mgHC} \mathrm{g}^{-1}$ rock is shown by the Sarnoo siltstones (Table 1).

The hydrogen index of the Giral samples ranges between $70-433 \mathrm{mgHC} \mathrm{g}{ }^{-1}$ TOC. For the Sarnoo siltstone, the $\mathrm{HI}$ values range between $300-500 \mathrm{mgHC} \mathrm{g}^{-1} \mathrm{TOC}$ (Table 1). The oxygen index (OI) value shows a relatively smaller range for the Giral samples than for the Sarnoo siltstones. A lower OI for Giral mines sample suggests good preservation of sedimentary organic matter. $\mathrm{T}_{\max }$, the temperature at which maximum amount of hydrocarbon generates by cracking of kerogen, for the Giral sample suggests a range between 412 to $468^{\circ} \mathrm{C}$. Majority of samples of lignites and shaly lignites are in immature stage with $\mathrm{T}_{\max }<435{ }^{\circ} \mathrm{C}$, except the shale samples, which represent a mature stage with $\mathrm{T}_{\max }>435{ }^{\circ} \mathrm{C}$. The Sarnoo siltstone shows an anomalous $\mathrm{T}_{\max }$ range of $320-608^{\circ} \mathrm{C}$.The lean TOC and, thus, low S2 values of the Sarnoo siltstone leads to such Tmax, which is the temperature at which the maximum release of hydrocarbons from cracking of kerogen occurs during pyrolysis (top of S2 peak). With low values of S2 for samples with TOC $<0.5 \%$, the Tmax of Rock Eval is considered uncertain (Mani et al., 2014).

The pyrolysis parameters characterize the source rock reliably. Correlation between the HI and OI, or the pseudo-Van Krevlen plot, helps in distiguishig the kerogen type. Here, the HI vs. OI 
plot shows a dominant Type-III kerogen (terrestrial organic matter input) for the Giral samples, whereas an altered organic matter input is indicated for the Sarnoo siltstone region (Fig. 6). The HI vs. $\mathrm{T}_{\max }$ coralation shows the Giral samples to be mainly Type-III to IV gas-prone kerogen, with most of the samples being immature, except for shales. The Sarnoo siltstone shows a lean kerogen, with extremely immature variety (Fig.7). The S2 and TOC represent Sarnoo siltstone to be poor with respect to organic matter content and hydrocarbon generation potential. The Giral lignites have excellent organic matter content and generation potential, followed by good to very good OM concentration with a fair generation potential for shaly lignites and fair OM content with a poor generation potential for shales (Fig.8). Production index (PI)-T $\max$ plot shows that all shale samples lie in the hydrocarbon generation field, along with some shaly lignite samples, whereas most of the Sarnoo siltstone bear inert carbon and non-indigenous hydrocarbon signatures (Fig.9). HI vs. S2/S3 plot shows that all the Sarnoo samples are inert type. The Giral samples show a dominant input of Type-III kerogen with gas generation potential, except a single sample (Fig. 10). 


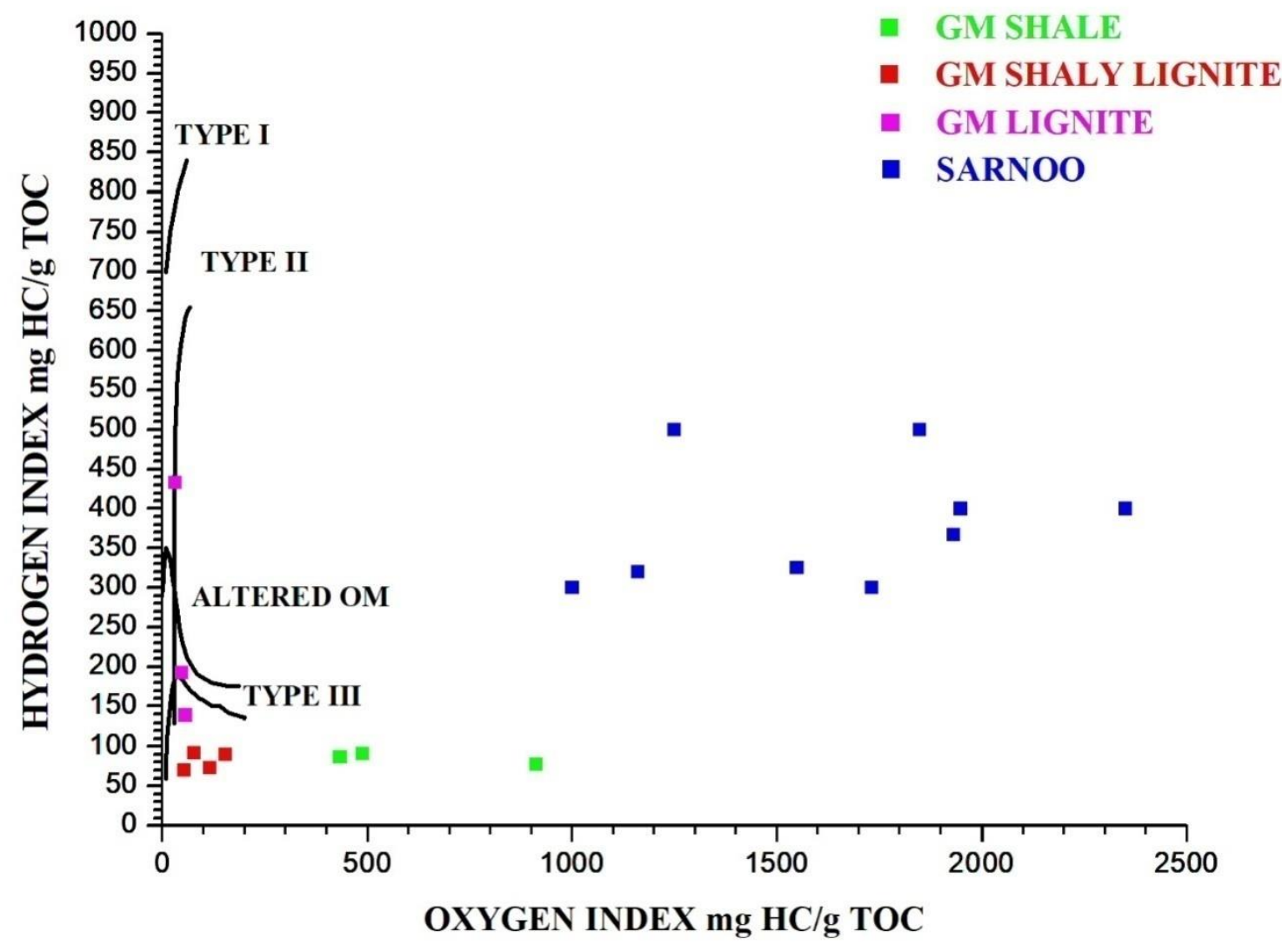

Fig. 6. Cross plot (modified after Van Krevlen, 1961) of HI vs. OI plot shows the kerogen Types for Barmer samples. GM: Giral Mine. 


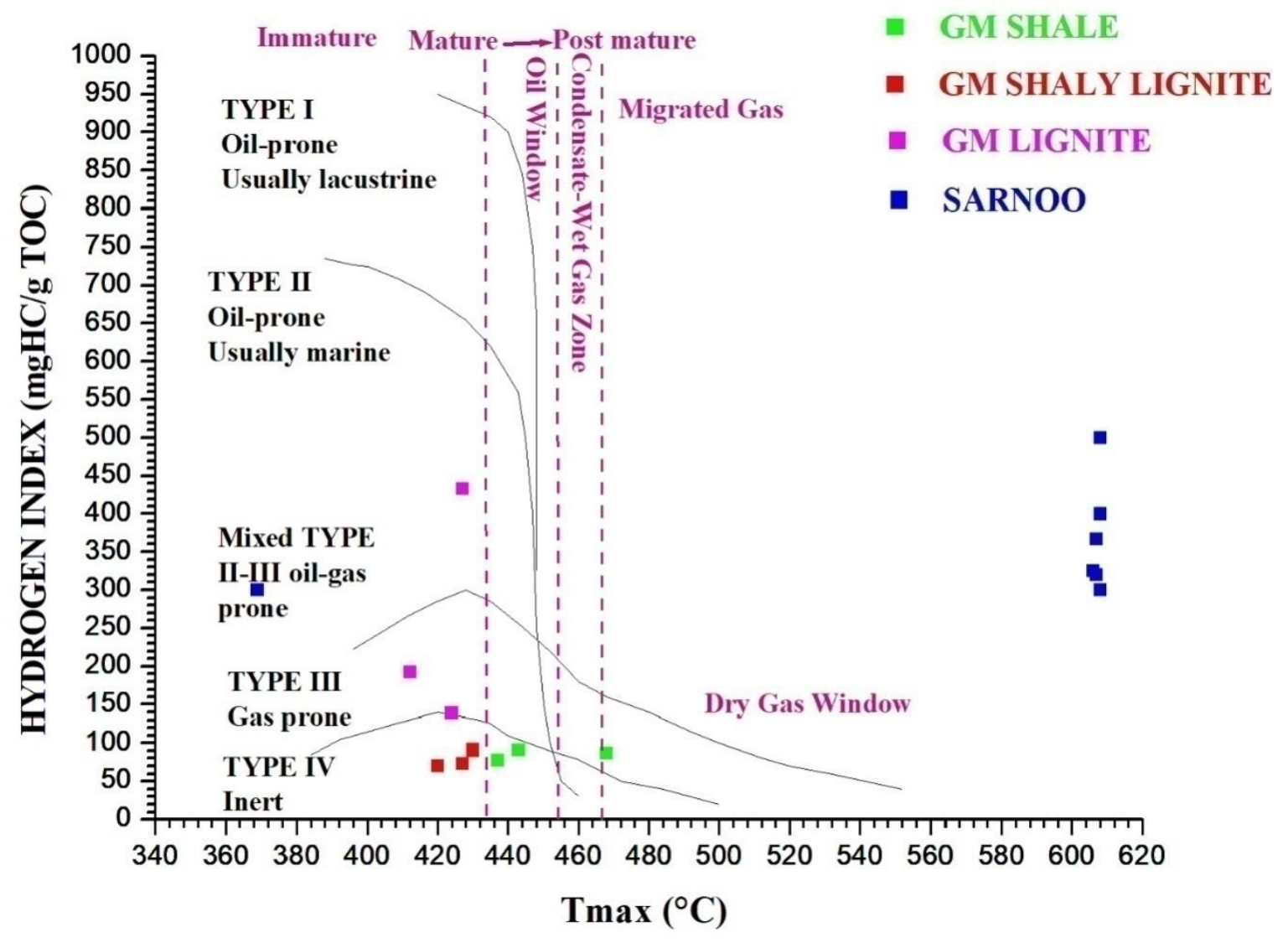

Fig.7. Cross plot of HI vs. $T_{\max }$ to show kerogen Type and maturity. GM: Giral Mine. 


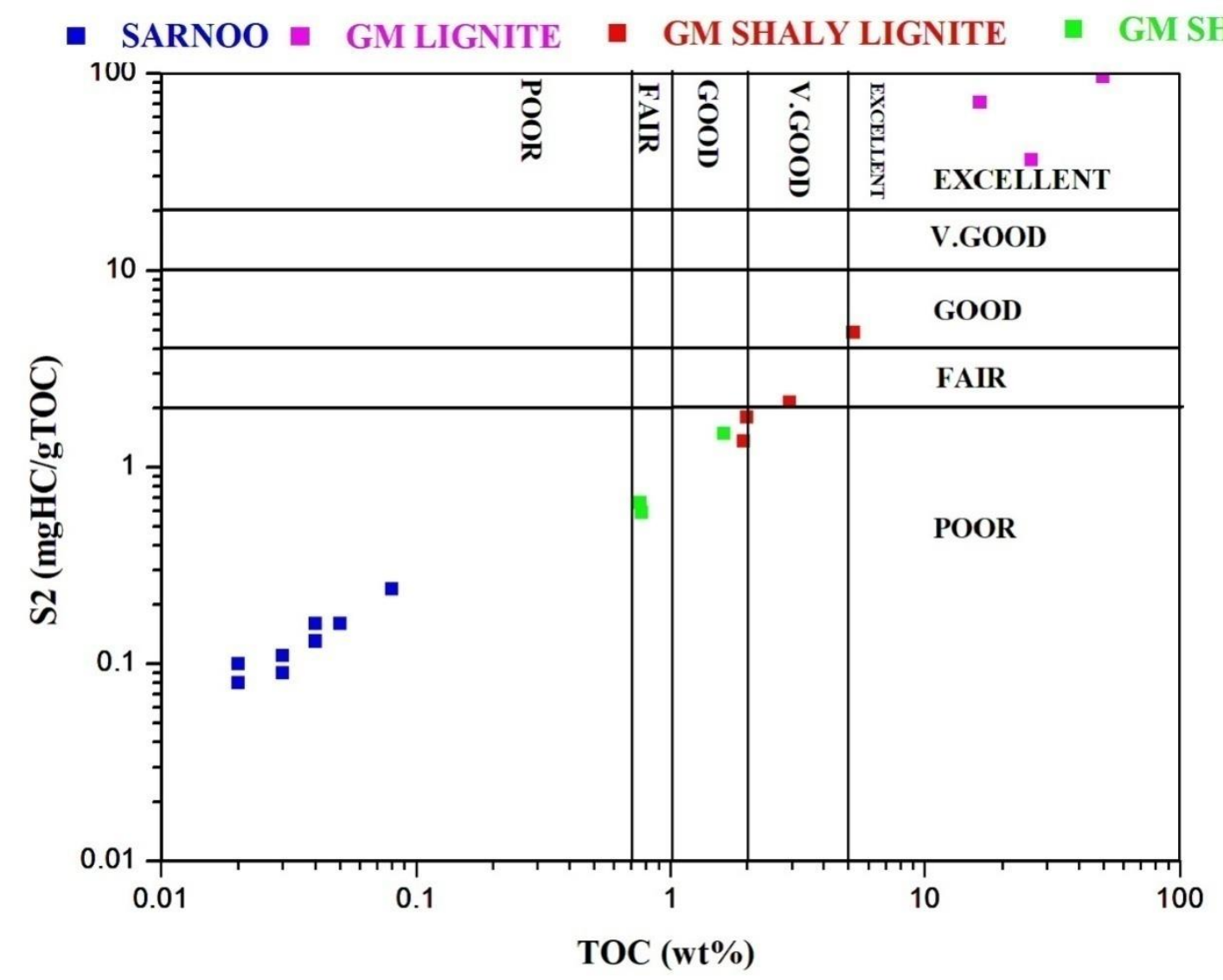

Fig. 8. Cross plot of S2 vs. TOC to categorize the rock based on its organic matter concentration and generation potential. GM: Giral Mine. 


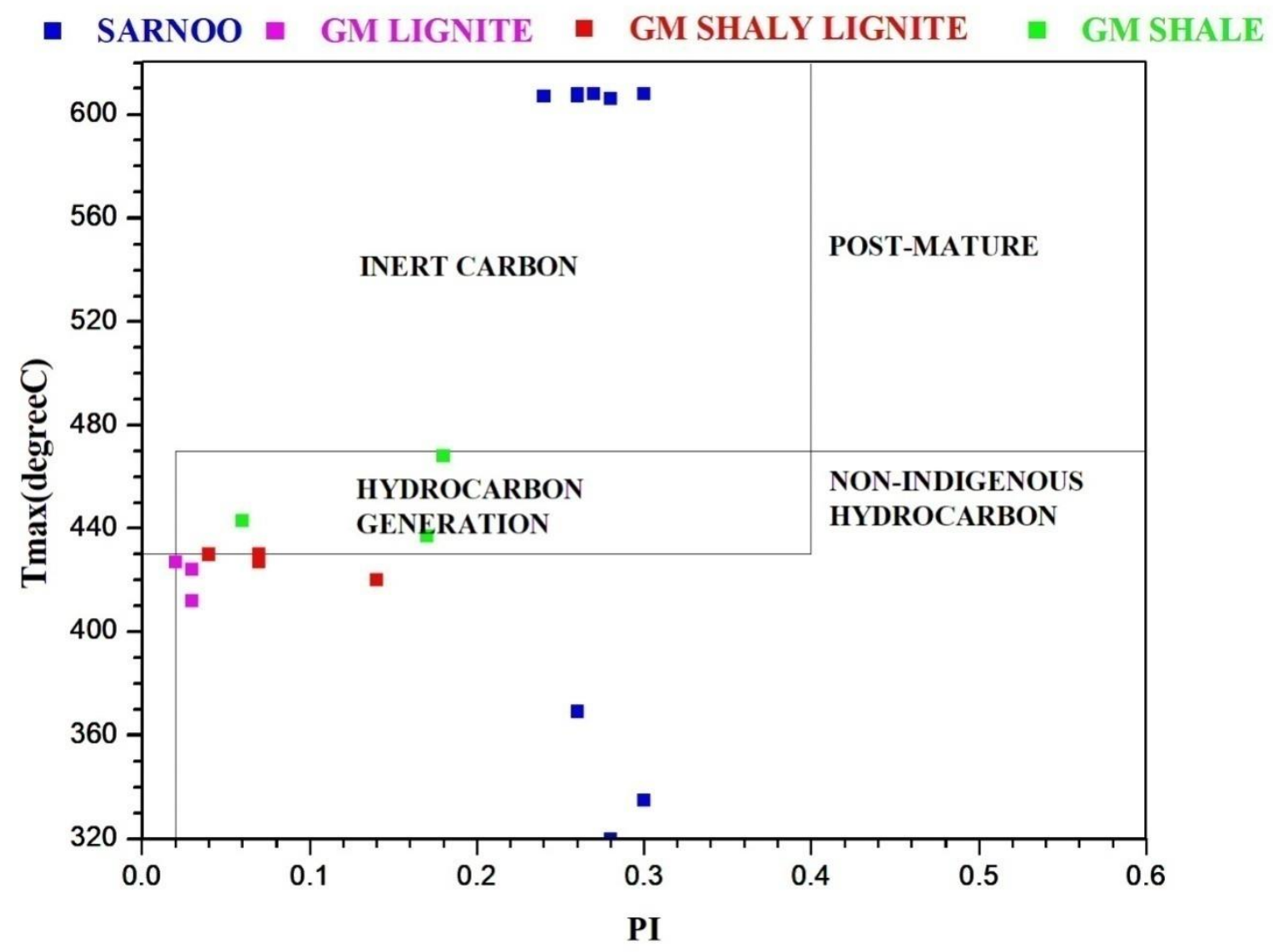

Fig. 9. Cross-plot of $T_{\max }$ and PI shows the hydrocarbon generation potential of the samples. 


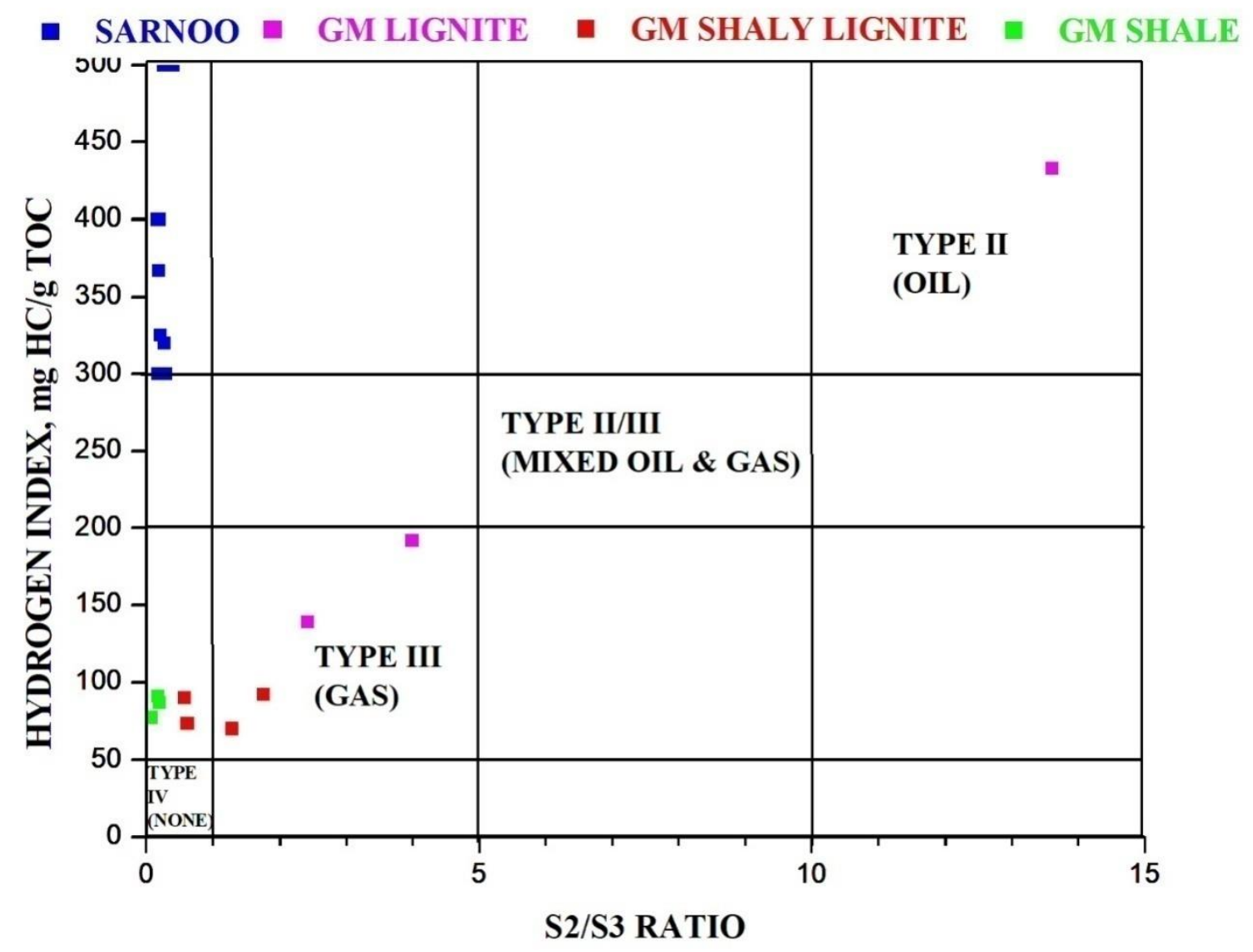

Fig 10._Cross-plot between HI and S2/S3 ratio to show the generation potential of the rocks (Peters and Cassa, 1994; modified after Richard et al. 2014).

Vitrinite reflectance, a parameter used to determine the maturity of organic matter, can be calculated using the Rock Eval $\mathrm{T}_{\max }$ (Jarvie et al., 2001). It is denoted by EVRo, where

$\% \mathrm{EVR}_{\mathbf{0}}=\left(0.0180 * \mathrm{~T}_{\max }\right)-7.16 \quad($ eqn 4$)$

The computed vitrinite reflectance values of the Giral samples lie in the immature to oil zone stage, except one sample with a wet gas maturity stage. Because of its very low TOC, the Sarnoo siltstone region shows that the samples have reached the dry gas zone stage (Table 1; Fig. 11). 


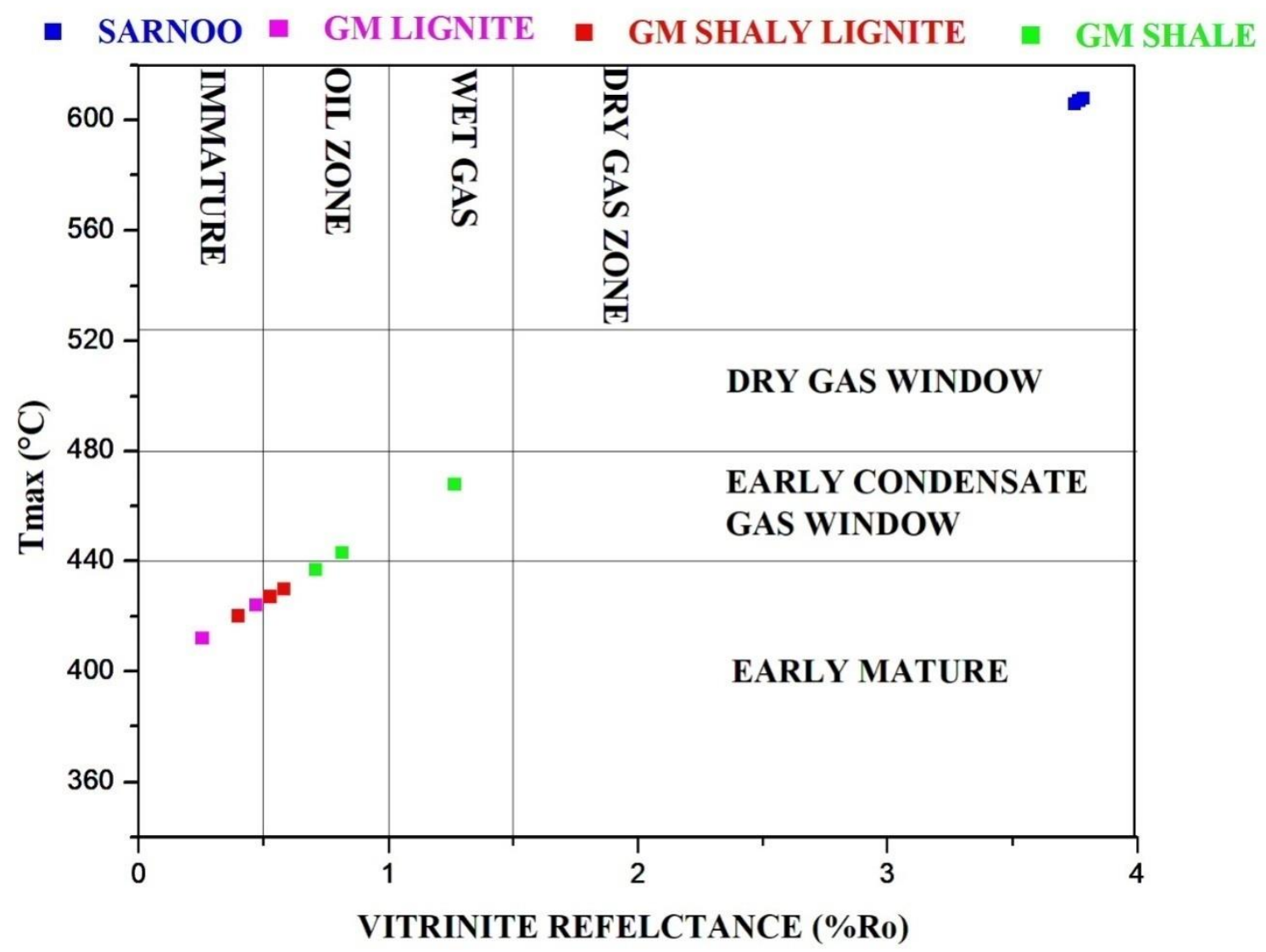

Fig. 11. Cross plot of $T_{\max }$ vs. EVRo shows the degree of organic matter maturity.

\subsection{Kerogen decomposition kinetics}

Five Giral samples were selected to study the kerogen decomposition kinetics, based on their maturity and organic matter contents. All the samples show broad activation energy (52-84 kcal mole ${ }^{-1}$ ) with a peak of $62-64 \mathrm{kcal}^{\mathrm{mole}}{ }^{-1}$ representing a strong heterogeneous type of organic matter input (Fig. 12). The hydrocarbon generation rate for these samples suggests a higher potential between the temperatures of 360 to $540^{\circ} \mathrm{C}$, indicating a faster generation rate. $\mathrm{T}_{\max }$ shifts towards the higher temperature upon increasing the heating rate (Fig. 13). Kerogen transformation ratio (KTR) can be grouped into different phases based on the amount of 
transformation, as the onset of transformation (10\% KTR), end phase of transformation (90\% KTR) and the middle phase (50\% KTR) (Mani et al., 2015). Maximum amount of kerogen transformation occurs between $10-90 \%$ KTR. Here the effective transformation of the samples occurs between $400-650{ }^{\circ} \mathrm{C}$, a range indicating an earlier but relatively slower transformation (Fig. 14). 


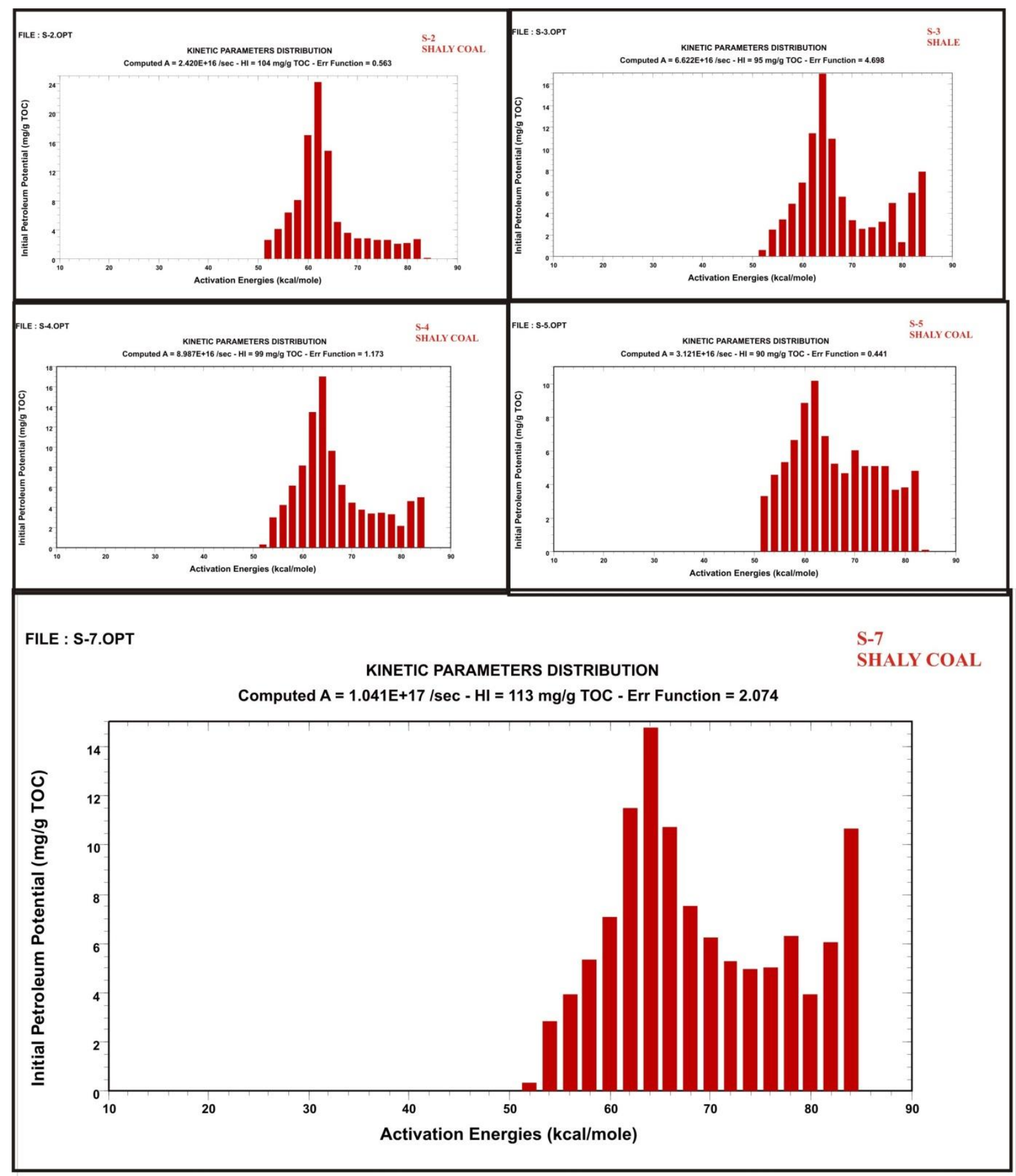

Fig. 12. Distribution of activation energy of the selected immature Giral samples. 


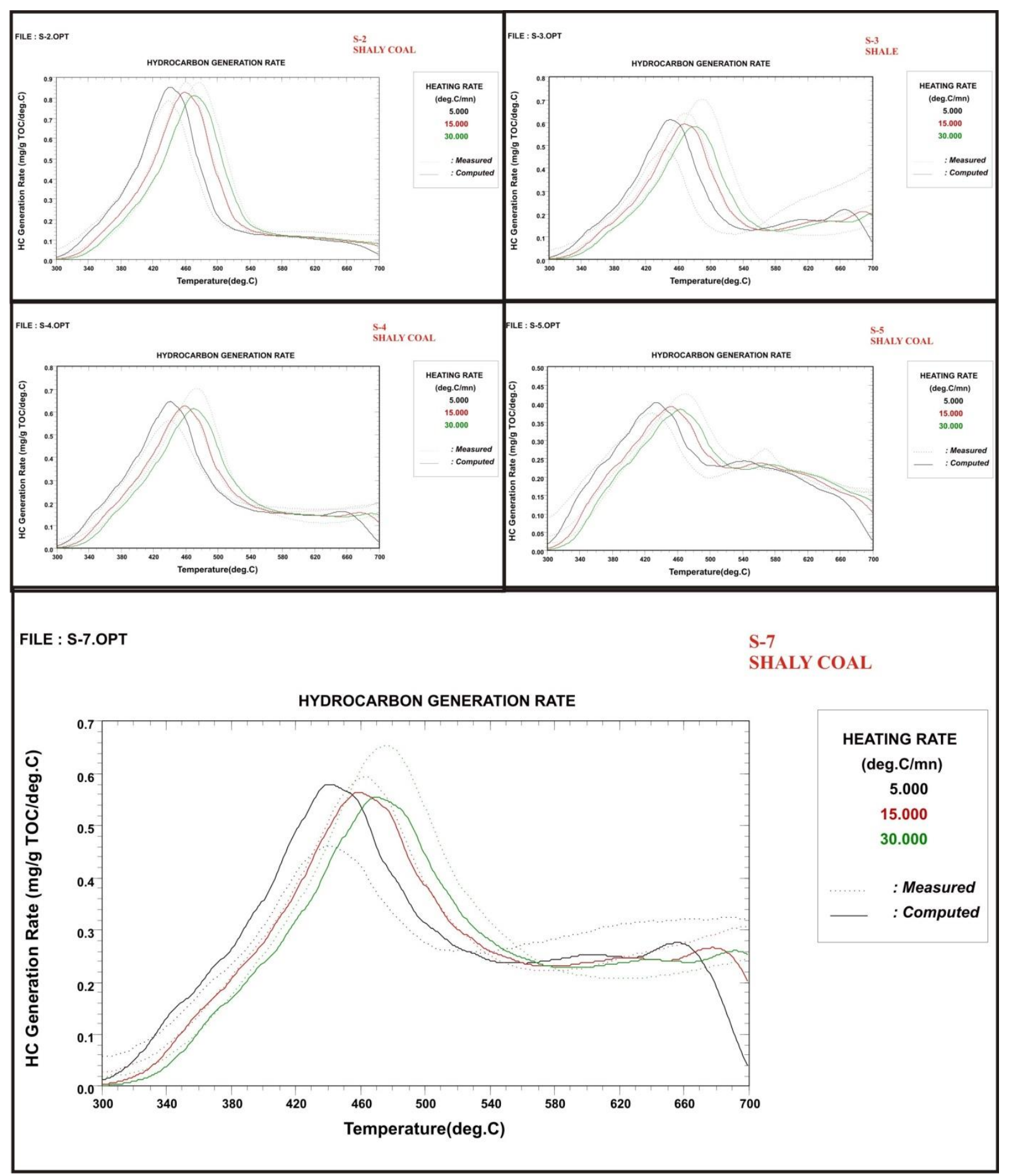

Fig. 13. Hydrocarbon generation rate of the selected immature Giral samples. 


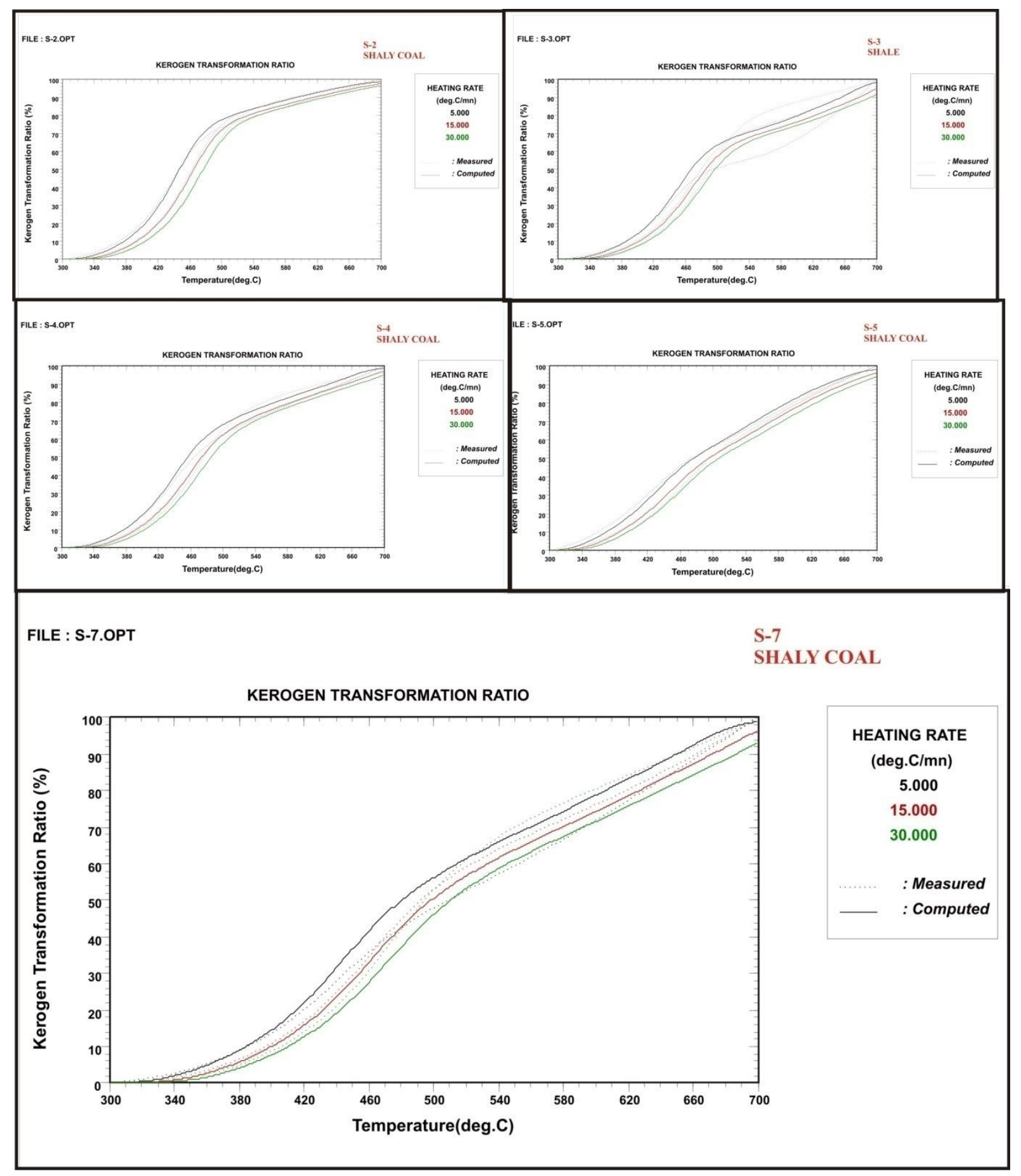

Fig. 14. Kerogen transformation ratio of the selected immature Giral samples. 


\section{Discussions}

\subsection{Organic matter richness and thermal maturity}

Amongst the investigated Giral samples, lignite is characterised by relatively higherorganic matter content, followed by shaly lignite and shale. Similarly, the generation potential is higher for lignites, followed by shaly lignites and shales. The higher S2 value of coal and shaly coal represents greater H-C generation potential. Also, the S2 peak of these rock show a significantly higher value than S1, suggesting these rocks to be source rock (Rajak et al., 2021). Besides the higher generation potential of the rocks, a relatively low thermal maturity of the samples indicates that unsuitability of these towards natural hydrocarbon generation, however these can be promising candidate for the artificial treatment for oil and gas production. Amongst the examined samples, lignite represents the highest TOC and generation potential followed by shaly lignite and shale, while the maturity (indicated by $\mathrm{T}_{\max }$ value) shows an opposite trend. It is highest for shale, followed by shaly lignite and lignite, representing a higher compaction for the shale samples than of coal.

EVRo values ranging between $0.5-0.6 \%$ and suggest thermogenic gas generation stage (Tissot et al., 1987; Clayton. 1998; Hunt, 1996; Moore et al., 2014), whereas magnitudes $\geq 1-1.2 \%$ indicates the peak gas generation stage (Michael et al., 1993; Tissot and Welte, 1984). The shale samples show the highest maturity in range of oil to gas zone, whereas other samples are relatively immature to early oil zone maturity. An overall $0.6 \%$ EVRo value of the Giral samples suggests an early stage of thermogenic early gas generation. 
Hydrogen index (HI) can be considered as an important factor for determining the kerogen type. Table 2 presents the relationship between HI and kerogen type. For Giral samples, the HI value varies between $70-433 \mathrm{mg} \mathrm{HCg}^{-1} \mathrm{TOC}$, with an average of $134.4 \mathrm{mg} \mathrm{HC} \mathrm{g}^{-1} \mathrm{TOC}$. It represents a dominant input from the Type-III gas prone kerogen. Besides, there is an overall decrease of the HI value with the increasing TOC value, which represents input of more gas-prone heterogeneous type organic matter to the basin (Raju et al., 2013).

Table 2._Relationship between HI and Kerogen Type (after Hakimi et al., 2012a, b, 2013; Verma et al., 2015).

\begin{tabular}{|l|l|}
\hline Hydrogen Index $\left(\mathbf{m g H C ~}^{-1} \mathbf{~ T O C}\right)$ & Kerogen Type \\
\hline 600 & Type-I \\
\hline $300-600$ & Type-II \\
\hline $200-300$ & Mixed Type II-III \\
\hline $50-150$ & Type-III \\
\hline$<50$ & Type-IV \\
\hline
\end{tabular}

A very high oxygen index value of Sarnoo region represents complete oxidation of the organic matter. These samples are characterised by their exceptionally lower TOC value of 0.02-0.08 $\mathrm{wt} \%$ and generation potential of $0.08-0.24 \mathrm{mgHC} \mathrm{g}^{-1}$ rock (Table 1). 


\subsection{Kerogen transformation $\&$ generation potential}

Kerogen degrades and transforms into oil and gas. Transformation of oil from complex kerogen is called primary cracking, which involves multiple parallel reactions, whereas the secondary cracking represents the transformation of oil to gas by simple reactions (Espitalie et al., 1987). These reactions obey the first-order kinetics law and the rate constant involved in these reactions follows the Arrhenius equation (Pitt, 1961; Tissot and Espitalie, 1975). Hence, a kinematic model can be used to study these samples to know its type of organic matter input, hydrocarbon generation rate and kerogen transformation ratio. These are important to predict the total amount of hydrocarbon generated during the categenesis and metagenesis (Espitalie et al., 1987).

The distribution of activation energy depends upon the type of bonds present in an organic compound, and gives insights on the type of kerogen present. Different bonds possess different bond rupture energies. The kerogen consisting of heterogeneous organic matter (Type III) shows a broader activation energy distribution than that with a homogeneous organic matter (TYPE I) (Espitalie et al., 1987). Type-I kerogen, sourced from lacustrine homogenous organic matter, is governed by a very narrow activation energy distribution (Espitalie et al., 1987). The Giral samples show a broader range of activation energy distribution ranging between 52 to 84 kcal mole $\mathrm{e}^{-1}$ with a peak of 62-64 kcal mole $\mathrm{k}^{-1}$. This suggests a heterogeneous type (Type-III kerogen) organic matter input to the area (Fig. 12).

The hydrocarbon generation rate (HGR) of the samples can be used for classifying the type of organic matter input. A narrow temperature range in the HGR curves represents homogeneous 
samples, whereas broader temperature range suggests heterogeneous organic matter input (Espitalie et al., 1987). For the examined samples, the temperature range of HGR shows a broader range of $360-540{ }^{\circ} \mathrm{C}$, suggesting an input from the heterogeneous Type-III organic matter. But a relatively earlier temperature of transformation of these samples suggests that these rocks can easily transform to their hydrocarbon generation stage artificially. There is also a shift of the $T_{\max }$ value towards the higher temperature range, marked with an increasing heating rate. This represents an earlier maturity of the samples at a slower geothermal gradient (Fig. 13).

The kerogen transformation ratio (KTR) is used to categorize the kerogen type and its transformation potential. A sudden spike of KTR with a steep slope is marked by the presence of a homogeneous Type-I kerogen, whereas for heterogeneous Type-II and III kerogens, the transformation is not sudden and the slope is gentle (Tissot and Espitalie, 1975; Mani et al., 2015). Thus, for a homogeneous kerogen, there is a smaller temperature range required for the transformation, whereas for a heterogeneous organic matter, the transformation requires a broader range. The examined samples indicate a relatively gentle slope with a broader temperature range for the transformation. This indicates heterogeneous input of organic matter, but with a quicker transformation, mostly between $10-70 \%$ of the KTR. This suggests that the organic matter possesses a good potential for the transformation into hydrocarbon (Fig. 14).

Thus, the Giral lignites and some shaly lignites are promising in terms of their organic matter content and hydrocarbon generation potential. The shale formations are organically lean and possess a low generation potential. In contrast, the lignite and shaly lignite formations are less 
mature than the shales. But the higher generation potential of these lignites and shaly lignites makes them suitable for the transformation into oil and gas through coal liquefaction and gasification, respectively. This is also supported by observing the earlier hydrocarbon generation temperatures and the relatively faster kerogen transformation ratio of the samples.

\section{Conclusions}

Using multiple organic geochemical properties, this study characterizes the source rock and hydrocarbon generation potential of the Paleogene shales/shaly lignitesof the Giral mine and Cretaceous Sarnoo siltstsones. The pseudo-Van Krevlen kerogen typing and a broader range of activation energy (52-84 $\mathrm{kcal} \mathrm{mole}^{-1}$; with a peak of $\left.62-64 \mathrm{kcal} \mathrm{mole}^{-1}\right)$ confirm that the Giral samples show dominantly Type-III heterogeneous kerogen. The organic matter has been better preserved due to the then reducing environment, which produced excellent TOC content of the lignites and shaly lignites (0.76-49.83 wt\%). The organically lean nature of the Giral Member shale is correlated with the higher subsidence rate over the peat accumulation during the genesis of lignites, leading to the dilution of organic matter content with high detrital material. However, high subsidence rate and elevated geothermal gradient were responsible for the higher maturity of these shales. The shaly lignites and lignites show immature to early oil window stage of hydrocarbon generation ( $\mathrm{T}_{\max }$ between $412-468{ }^{\circ} \mathrm{C}$ ). The higher $\mathrm{S} 2$ values (up to 95.9 mgHC/gTOC) over the $\mathrm{S} 1$ values for the samples also suggest these rocks are suitable to be considered for good source rocks for artificial transformations. Both KTR and HGR suggest the organic matter input to be mostly of terrestrial heterogeneous Type-III kerogen.A relatively earlier and faster temperature of transformation shows the samples are good to be transformed into artificially generated hydrocarbon resource. Lignites and shaly lignites, being rich in organic 
matter have a higher hydrocarbon generation potential and are suitable to be transformedinto different hydrocarbon products. Sarnoo region samples are weathered intensely and completely oxidized. These samples might be effective reservoirs, however those are unsuitable as source rocks. 
Acknowledgements: Funded by a seed project received from Center of Excellence in Oil, Gas and Energy, IIT Bombay (grant number RD/0120-PSUCE19-001) awarded to SM. Mr. S. C. Sharma (Head, CEU-Lignite, Barmer) permitted us to visit the Giral mine. Thanks to J. Shrikanth and S. N. Karnekar and for assisting SM in project-related paper works. Paramita Haldar (BITS Pilani, Goa Campus) assisted the fieldwork.

\section{Abbreviations:}

AE:

CBM:

DDF:

EVRo:

FID:

HGR:

HI:

IR:

KTR:

OI:

OM:

PI:
Activation energy

Coal bed methane

Dharvi Dungar Formation

Computed vitrinite reflectance value

Flame ionization detector

Hydrocarbon generation rate

Hydrogen Index

Infrared detector

Kerogen transformation ratio

Oxygen Index

Organic matter

Production index 
S1:

Amount of residual hydrocarbon

S2: Amount of hydrocarbon that gets generated from the thermal cracking of kerogen.

$\mathrm{T}_{\max }$ : Temperature at which maximum amount of hydrocarbon gets liberated by cracking of Kerogen.

TOC: Total Organic Carbon 


\section{References}

Kumar A, Singh AK, Paul D, Kumar A. 2020. Evaluation of hydrocarbon potential with insight into climate and environment present during deposition of the Sonari lignite, Barmer Basin Rajasthan. Energy and Climate Change 1, 100006.

Biswas M, Puniya MK, Gogoi MP, Dasgupta S, Mukherjee S, Kar NR (Accepted) Morphotectonic analysis of petroliferous Barmer rift basin (Rajasthan, India). Journal of Earth System Science.

Braun, R.L., Burnham, A.K., 1987. Analysis of chemical reaction kinetics using a distribution of activation energies and simpler models. Energy Fuels 1, 153-161.

Clayton, J.L., 1998. Geochemistry of coalbed gas—a review. Int. J. Coal Geol. 35, 159173.

Dasgupta S, Mukherjee S. (2017) Brittle shear tectonics in a narrow continental rift: asymmetric non-volcanic Barmer basin (Rajasthan, India). The Journal of Geology 125, 561-591.

Dasgupta S, Mukherjee S. (2019) Remote sensing in lineament identification: Examples from western India. In: Billi A, Fagereng A (Eds) Problems and Solutions in Structural Geology and 
Tectonics. Developments in Structural Geology and Tectonics Book Series. Vol. 5. Series Editor: Mukherjee S. Elsevier. ISSN: 2542-9000. ISBN: 9780128140482. pp. 205-221.

Dolson J. 2016. Understanding Oil and Gas Shows and Seals in the Search for Hydrocarbons. Springer. ISBN 978-3-319-29710-1.

Dolson, J., Burley, S. D., Sunder, V. R., Kothari, V., Naidu, B., Whiteley, N. P., Farrimond P, Taylor A, Ananthakrishnan, DB. (2015). The discovery of the Barmer Basin, Rajasthan, India, and its petroleum geology. AAPG Bulletin, 99(3), 433-465.

Espitalie, J., Marquis, F., Sage, L., 1987. Organic geochemistry of the Paris Basin. In: Brooks, J., Glennie, K. (Eds.), Petroleum Geology of North West Europe. Graham and Totman, London, pp. $71-86$.

Farrimond, P., Naidu, B. S., Burley, S. D., Dolson, J., Whiteley, N., \& Kothari, V. (2015). Geochemical characterization of oils and their source rocks in the Barmer Basin, Rajasthan, India. Petroleum Geoscience, 21(4), 301-321.

Hunt, J.M., 1996. Petroleum Geochemistry and Geology.2nd ed. W.H. Freeman and Company, New York (743 pp.). 
Jarvie, D.M., 1991. Factors affecting Rock-Eval derived kinetic parameters. Chem. Geol. 93, 7999.

Jarvie, Daniel M., Claxton, Brenda L., Henk, Floyd “Bo”, Breyer, John T., 2001. Oil and shale gas from the Barnett Shale, Ft. Worth Basin, Texas. AAPG National Convention, June 3-6, 2001, Denver, CO. AAPG Bull. 85, p. A100 (No. 13, Supplement).

Juntgen, H., and J. Klein, 1975, Entstehung von Erdgasaus Kohligen Sedimenten: Erdoel und Kohle-Erdgas-Petrochemie, v. 28, p. 65- 73.

Khanolkar S, Sharma J. 2019. Record of Early to Middle Eocene paleoenvironmental changes from lignite mines, western India. Journal of Micropalaeontology 38, 1-24.

Mahlstedt, N.L., Horsfield, B., 2012. Metagenetic methane generation in gas shales I. Screening protocols using immature samples. Mar. Pet. Geol. 31, 27-42.

Mani D, Patil DJ, Dayal AM, Kavitha S, Hafiz M, Hakhoo N, Bhat GM, 2014. Gas potential of Proterozoic and Phanerozoic shales from the NW Himalaya, India: Inferences from pyrolysis. International Journal of Coal Geology 128, 81-95 
Mani D, Patil DJ, Dayal AM, Prasad BN, 2015. Thermal maturity, source rock potential and kinetics of hydrocarbon generation in Permian shales from the Damodar Valley basin, Eastern India, Marine and Petroleum Geology 66 1056-1072, ISSN 0264-8172.

Michael, G.E., Anders, D.E., Law, B.E., 1993. Geochemical evaluation of Upper Cretaceous Fruitland Formation coals, San Juan Basin, New Mexico and Colorado. Org. Geochem. 20, 475498.

Moore, T.A., Bowe, M., Nas, C., 2014.High heat flow effects on a coalbed methane reservoir, East Kalimantan (Borneo), Indonesia.Int. J. Coal Geol. 131, 7-31.

Mukherjee S, Bose N, Ghosh R, Dutta D, Misra AA, Kumar M, Dasgupta S, Biswas T, Joshi A, Limaye M. 2020. Structural Geological Atlas. Springer. ISBN: 978-981-13-9825-4.

Oldham RD (1886) Geology of Northern Jaisalmer. Rec. Geol. Surv. Ind. 19, 157-159.

Pandey, D. K., J. Sha, and S. Choudhary, 2010, Sedimentary 1357 cycles in the CallovianOxfordian of the Jaisalmer Basin, 1358 Rajasthan, India: Volumina Jurassic 9, p. 131-162. 
Paul S, Dutta S. 2016. Terpenoid composition of fossil resins from western India: New insights into the occurrence of resin-producing trees in Early Paleogeneequatorial rainforest of Asia. International Journal of Coal Geology 167, 65-74.

Peters, K.E., Cassa, M.R., 1994. Applied source rock geochemistry. In: Magoon, L.B., Dow, W.G. (Eds.), The Petroleum System from Source to Trap. AAPG, Memoir vol. 60, pp. 93-120.

Pitt G. J. (1961) The kinetics of the evolution of volatile products from coal. 4th Int. Conf. on Coal Science, Le Touquet, France, May 30-June 2, 1961.

Prasad V, Uddaadam PR, Agarwal S, Bajpai S, Singh I, Mishra AK, Sharma A $<$ Kumar M, Verma P. 2020. Biostratigraphy, palaeoenvironment and sea level changes during pre-collisional (Palaeocene) phase of the Indian plate: palynological evidence from Akli Formation in Giral Lignite Mine, Barmer Basin, Rajasthan, Western India. Episodes 476-488.

Rajak, P. K., Singh, V. K., Kumar, A., Singh, V., Rai, A., Rai, S.,\& Singh, P. K. (2021). Study of Hydrocarbon Source Potential of Kapurdi Lignites of Barmer Basin, Rajasthan, Western India.Journal of the Geological Society of India, 97(8), 836-842.

Rajak PK, Singh VK, Singh PK, Singh AL, Kumar N, Kumar OP, Singh V, Kumar A(2018). Geochemical implications of minerals and environmentally sensitive elements of Giral lignite, 
Barmer Basin, Rajasthan (India).Environmental Earth Sciences.77: 698.10.1007/s12665-018$7885-5$.

Rajkumari P, Guntupalli VR P. 2020. New chondrichthyan fauna from the Palaeogene deposits of Barmer district, Rajasthan, western India: Age, palaeoenvironment and intercontinental affinities. Geobios 58, 55-72.

Raju, S. V., \& Mathur, N. (2013). Rajasthan lignite as a source of unconventional oil.Current Science 104, 752-757.

Rana, S.R., Singh, H., Rose, D.K., 2005. Lower vertebrates from the Late Palaeocene- Earliest Eocene Akli Formation, Giral Lignite Mine, Barmer District, Western India.Current Science 89, 1606-1613.

Rodriguez, N.D., Philp, R.P., 2010.Geochemical characterization of gases from the Mississippian Barnett Shale, Fort Worth Basin, Texas.AAPG Bull. 94 (11), 1641-1656.

Roy A B, Jakhar S R (2002). Geology of Rajasthan (Northwest India) Precambrian to Recent. Scientific Publishers, Jodhpur, pp 1-421. 
Siddiquie HN (1963) The jodhpur-malani divide separating the Barmer and Jaisalmer basins. Geol. Soc. Ind. 4:97-107.

Singh A, Kumar A, Singh PK, Singh AL, Kumar A. Bacterial desulphurization of low-rank coal: A case study of Eocene Lignite of Western Rajasthan, India. Energy Sources, Part A: Recovery, Utilization, and Environmental Effects 40, 1199-1208.

Singh H (2015) Palynofloral investigation of the Akli Formation (Palaeocene) of Giral Lignite Mine, Barmer District, Rajasthan. Geophytology 45, 209-214.

Singh, P. K., Rajak, P. K., Singh, M. P., Singh, V. K., Naik, A. S., \& Singh, A. K. (2016). Peat swamps at Giral lignite field of Barmer basin, Rajasthan, Western India: understanding the evolution through petrological modelling. International Journal of Coal Science \& Technology, $3,148-164$.

Stanley, R. G., Lillis, P. G., Pawlewicz, M. J., \& Haeussler, P. J. (2013). Rock-Eval pyrolysis and vitrinite reflectance results from the Sheep Creek 1 well, Susitna basin, south-central Alaska. US Geological Survey Open-File Report, 1307, 2014.

Tang, Y., Jenden, P.D., Nigrini, A., Teerman, S.C., 1996.Modeling early methane generation in coal.Energy Fuel 10, 659-671. 
Taylor, G.H., Teichmüller, Davis, A., Diessel, C.F.K., Littke, R., Robert, P., 1998. Organic Petrology. Gerbrüder Borntraeger, Berlin (704 pp.).

Teichmüller, M., 1987. Recent advances in coalification studies and their application to geology. In: Scott, A.C. (Ed.), Coal and coal-bearing strata: recent advances. Geol. Soc. London Spec. Publ. vol. 32, pp. 127-169.

Tissot, B.P., Espitalie, J., 1975. Thermal evolution of organic matter in sediments: application of a mathematical simulation. Petroleum potential of sedimentary basins and reconstructing the thermal history of sediments.Rev. Inst. Fr. Petr. 30 (5), 743-778.

Tissot, B.P., Pelet, R., Ungerer, P., 1987. Thermal history of sedimentary basins, maturation indices, and kinetics of oil and gas generation. AAPG Bull. 71, 1445-1466.

Tissot, B.P., Welte, D.H., 1984. Petroleum Formation and Occurrence. 2nd Edn. Springer Verlag, Berlin, Heidelberg, New York, Tokyo.

Tripathi, S. K. M., Kumar, M. and Srivastava, D., 2009. Palynology of Lower Paleozoic (Thanetian-Ypresian) coastal deposits from the Barmer Basin (Akli Formation, western Rajasthan, India): palaeoenvironmental and palaeoclimaic implications. Geol. Acta 7, 142-160. 
Van Krevelin, D.W., 1961. Coal: Typology-chemistry-physics-constitution. Elsevier Science, Amsterdam. 